\title{
Analysis of Spent Ion Exchange Media: Superlig 639 and Superlig 644
}

\author{
D. E. Kurath \\ J. J. Wagner
}

May 2000

Battelle, Pacific Northwest Division

Richland, Washington 99352 


\section{DISCLAIMER}

This report was prepared as an account of work sponsored by an agency of the United States Government. Neither the United States Government nor any agency thereof, nor any of their employees, make any warranty, express or implied, or assumes any legal liability or responsibility for the accuracy, completeness, or usefulness of any information, apparatus, product, or process disclosed, or represents that its use would not infringe privately owned rights. Reference herein to any specific commercial product, process, or service by trade name, trademark, manufacturer, or otherwise does not necessarily constitute or imply its endorsement, recommendation, or favoring by the United States Government or any agency thereof. The views and opinions of authors expressed herein do not necessarily state or reflect those of the United States Government or any agency thereof. 


\section{DISCLAIMER}

Portions of this document may be illegible in electronic image products. Images are produced from the best available original document. 


\section{Summary}

The current BNFL Inc. flowsheet for the pretreatment of the Hanford high-level tank wastes includes the use of Superlig ${ }^{\circledR}$ materials ${ }^{(a)}$ for removing ${ }^{137} \mathrm{Cs}$ and ${ }^{99} \mathrm{Tc}$ from the aqueous fraction of the waste. The cesium-selective Superlig ${ }^{\circledR} 644$ (SL-644) and the technetium-selective Superlig ${ }^{\circledR} 639$ (SL 639) materials have been evaluated in tests with actual waste samples. These materials have a finite processing lifetime in the plant and will need to be disposed of. The composition and level of residual radionuclide contamination is important for assessing various disposal pathways for the spent Superlig ${ }^{\circledR}$ materials.

This report contains the results of analyzing subsamples of the SL-639 and SL 644 materials that have been used in small-column testing of actual waste samples at the Radiochemical Processing Laboratory. The wastes that have been tested include samples from Tanks 241-AW-101 (Envelope A) and 241-AN107 (Envelope $C$ ). The spent resins were analyzed with inductively coupled plasma/atomic emission spectrometry (ICP-AES) for metals, cold vapor atomic absorption (CVAA) spectroscopy for mercury, gamma energy analysis (GEA) for radionuclides, and inductively coupled plasma/mass spectrometry (ICP-MS) for selected metals and radionuclides.

The analytes of interest that were detected at levels above the minimum reportable quantities (MRQs) are given in Table S1. The results for both samples contain the contribution from interstitial liquid, which was $<0.1 \mathrm{M} \mathrm{NaOH}$ for SL-644 and deionized (DI) water for SL-639. All specified MRQs were readily met, and the quality control checks met the requirements of the governing quality assurance (QA) plan. Since the detection limits were generally well below the MRQs, the concentrations of many other analytes of interest may be found in the body of the report. While these results provide an indication of the analyte concentrations that may be left on the spent resin, they do not fully represent the concentrations that may be found after extended plant processing with additional load/elute cycles and different waste compositions.

(a) These materials have been developed and supplied by IBC Advanced Technologies, Inc., American Fork, Utah. 
Table S1. Analytes of Interest Detected at Levels Above the MRQs

\begin{tabular}{|c|c|c|c|c||}
\hline Analyte & SL-644 & SL-639 & MRQ & Method \\
\hline & $\mu \mathrm{g} / \mathrm{g}$ & $\mu \mathrm{g} / \mathrm{g}$ & $\mu \mathrm{g} / \mathrm{g}$ & \\
\hline $\mathrm{Cr}$ & 670 & - & 100 & \multirow{2}{*}{ ICP-AES } \\
\hline $\mathrm{K}$ & 220 & 160 & 60 & \multirow{2}{*}{ ICP-MS } \\
\hline $\mathrm{Na}$ & 83,800 & -- & 5,400 & \\
\hline${ }^{99} \mathrm{Tc}$ & 6.74 & 6.95 & 2.0 & 6.0 \\
\hline${ }^{238} \mathrm{U}$ & 14.8 & -- & $\mu \mathrm{Ci} / \mathbf{g}$ & \multirow{2}{*}{ GEA } \\
\hline & $\mu \mathrm{Ci} / \mathbf{g}$ & $\mu \mathrm{Ci} / \mathbf{g}$ & 0.12 & 0.01 \\
\hline${ }^{60} \mathrm{Co}$ & 1.31 & -- & - & 0 \\
\hline
\end{tabular}




\title{
Terms and Abbreviations
}

\author{
BNFL BNFL, Inc; subsidiary of British Nuclear Fuels, Ltd. \\ BV bed volume \\ $\mathrm{C} / \mathrm{C}_{0} \quad$ analyte concentration in column effluent divided by analyte \\ concentration in feed \\ CVAA cold vapor atomic absorption \\ DI deionized water \\ GEA gamma energy analysis \\ ICP-AES inductively coupled plasma/atomic emission spectrometry \\ ICP-MS inductively coupled plasma/mass spectrometry \\ MDL method detection limit \\ MRQ minimum reportable quantity \\ QA quality assurance \\ RPP-WTP River Protection Project-Waste Treatment Plant
}




\section{Contents}

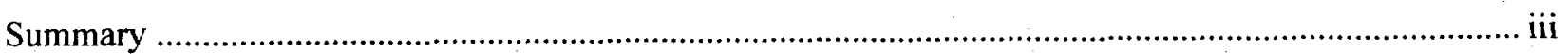

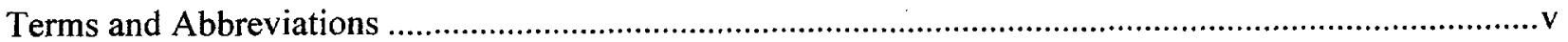

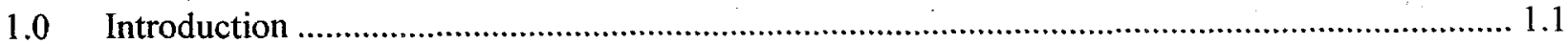

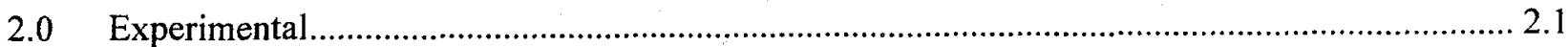

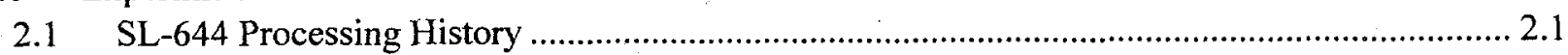

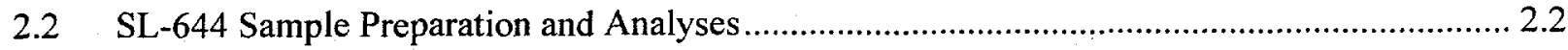

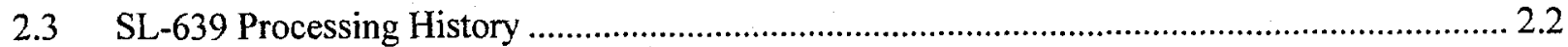

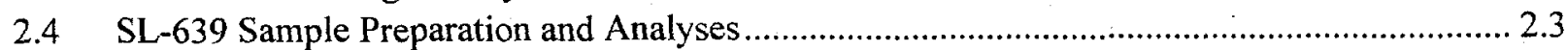

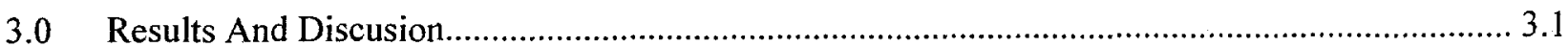

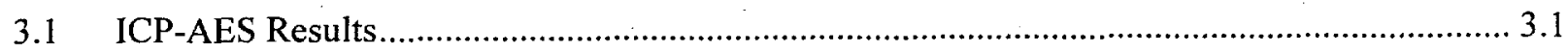

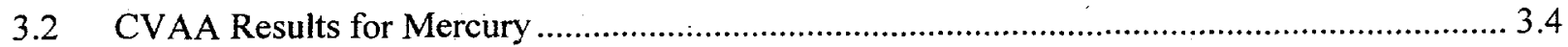

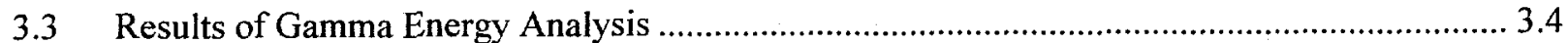

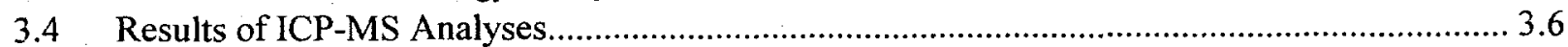

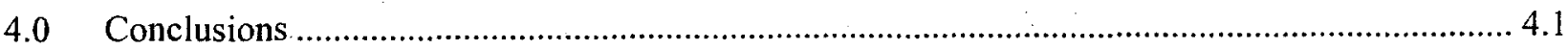

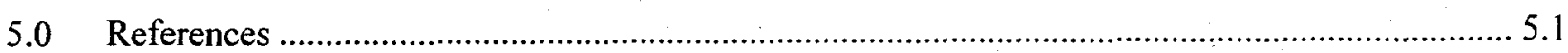

Figures

Figure A.1. Flow sheet for Analytical Preparation of SL-644 ......................................................... 1

Figure A.2. Flow sheet for Analytical Preparation of SL-639 ......................................................2 


\section{Tables}

Table S1. Analytes of Interest Detected at Levels Above the MRQs .......................................................iv

Table 2.1. Final ${ }^{137} \mathrm{Cs}$ and $\mathrm{C} / \mathrm{C}_{0}$ Values for the SL-644 Columns Used in Actual Waste Testing.............2.1

Table 2.2. Final ${ }^{95} \mathrm{Tc} \mathrm{C} / \mathrm{C}_{0}$ values for the SL-639 Columns Used in Actual Waste Testing ....................2.3

Table 3.1. ICP-AES Analysis of Spent SL-644 and SL-639 Resins and the MRQs ..............................3.2

Table 3.2. Comparison of ICP-AES Results for Spent SL-644 and SL-639 Resins to Cesium Ion

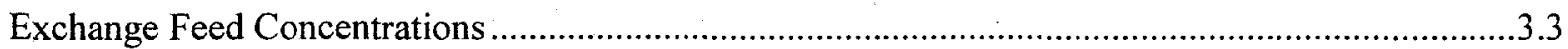

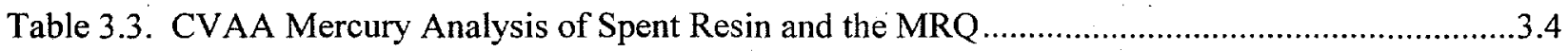

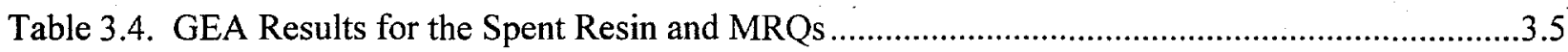

Table 3.5. Interstitial Liquid Radiochemical Results by Gamma Energy Analysis .................................3.5

Table 3.6. ICP-MS Analysis of Spent SL-644 Resin and the Minimum Reportable Quantities...............3.6 


\subsection{Introduction}

The current BNFL Inc. flowsheet for the pretreatment of the Hanford High-Level tank wastes includes the use of Superlig ${ }^{\circledR}$ materials ${ }^{(a)}$ for the removal of ${ }^{137} \mathrm{Cs}$ and ${ }^{99} \mathrm{Tc}$ from the aqueous fraction of the waste. The cesium-selective Superlig ${ }^{\circledR} 644$ (SL-644) and the technetium-selective Superlig ${ }^{\circledR} 639$ (SL-639) have been evaluated in tests with actual waste samples. These materials have a finite processing lifetime in the plant and will need to be disposed of. The composition and level of residual radionuclide contamination is important for assessing various disposal pathways for the Superlig ${ }^{\circledR}$ materials.

This report contains the results of analyses of subsamples of the SL-639 and SL 644 materials that have been used in small column testing of actual waste samples at the Radiochemical Processing Laboratory. The wastes that have been tested include samples from Tanks 241-AW-101 and 241-AN-107 (the 241 prefix is common to all Hanford tanks and will not be used hereafter). The analyses of the spent resins include inductively coupled plasma/atomic emission spectrometry (ICP-AES) for metals, cold vapor atomic absorption (CVAA) spectroscopy for mercury, gamma energy analysis (GEA) for radionuclides and inductively coupled plasma/mass spectrometry (ICP-MS) for selected metals and radionuclides.

While these results provide an indication of the analyte concentrations that may be left on the spent resin, they do not fully represent the concentrations that may be found after extended plant processing with additional load/elute cycles and different waste compositions. BNFL estimates that the SL-644 may last for 100 load/elute cycles with Envelope $A$ and $C$ wastes and 20 cycles with Envelope B wastes. ${ }^{\text {(b) }}$ The number of useable load/elute cycles for the SL-639 is not well defined, but is likely on the order of hundreds.

(a) These materials have been developed and supplied by IBC Advanced Technologies, Inc., American Fork, Utah.

(b) Specification 7 of Contract No. DE-RP06-96RL13308. 


\subsection{Experimental}

This section describes the sample processing history for the SL-644 and SL-639 resins and discusses the resin subsampling and preparation for the analytical procedures. ${ }^{a}$

\subsection{SL-644 Processing History}

The SL-644 resin was used in a small dual-column ion exchange system to remove cesium from samples of Tanks AW-101 (Envelope A) and AN-107 (Envelope C). The AW-101 sample was processed in June 1999 with the conduct of two complete loading cycles. Both columns were loaded, rinsed with deionized (DI) water, eluted with $0.5 \mathrm{M}$ nitric acid, rinsed with DI water, and regenerated with $0.1 \mathrm{M}$ $\mathrm{NaOH}$ (Kurath et al. 1999). The second loading cycle was conducted with the same AW-101 sample to remove residual cesium that was not removed during the first cycle. The $\mathrm{AN}-107$ sample was processed in October 1999 with a single load/elute cycle. All process steps were similar to those used in processing the AW-101 sample (Kurath et al. 2000). Since both columns were eluted after each run, the order of the columns was not switched.

The extent to which ${ }^{137} \mathrm{Cs}$ was removed from the columns before analysis is indicated in Table 2.1. The ${ }^{137} \mathrm{Cs}$ concentration and the ${ }^{137} \mathrm{Cs} \mathrm{C} / \mathrm{C}_{0}$ values (analyte concentration in column effluent divided by analyte concentration in feed) are shown for the final eluate samples for both columns and for the final rinse sample and composite regeneration sample for Column 1 . The $\mathrm{C}_{0}$ value is $153 \mu \mathrm{Ci} / \mathrm{mL}$ and corresponds to the ${ }^{137} \mathrm{Cs}$ concentration found in the $\mathrm{AN}-107$ cesium ion exchange feed sample. For reference, the target end point for elution is a $\mathrm{C} / \mathrm{C}_{0}=1 \mathrm{E}-02$.

Table 2.1. Final ${ }^{137} \mathrm{Cs}$ and $\mathrm{C} / \mathrm{C}_{0}$ Values for the SL-644 Columns Used in Actual Waste Testing

\begin{tabular}{|l|c|c|c|c|}
\hline & \multicolumn{2}{|c|}{ Column 1 } & \multicolumn{2}{c|}{ Column 2 } \\
\cline { 2 - 5 } & $\begin{array}{c}{ }^{137} \mathbf{C s} \text { Concentration } \\
\mu \mathrm{Ci} / \mathrm{mL}\end{array}$ & ${ }^{137} \mathrm{Cs} \mathbf{C} / \mathbf{C}_{\mathbf{0}}$ & $\begin{array}{c}{ }^{137} \mathrm{Cs} \text { Concentration } \\
\mu \mathrm{Ci} / \mathbf{m L}\end{array}$ & ${ }^{137} \mathbf{C s} \mathbf{C} / \mathbf{C}_{\mathbf{0}}$ \\
\hline Final Eluate Sample & $9.1 \mathrm{E}-01$ & $5.9 \mathrm{E}-03$ & 0.73 & $4.8 \mathrm{E}-03$ \\
\hline Final Rinse Sample & $5.5 \mathrm{E}-02$ & $3.6 \mathrm{E}-04$ & $\mathrm{ND}$ & $\mathrm{ND}$ \\
\hline $\begin{array}{l}\text { Composite } \\
\text { Regeneration sample }\end{array}$ & $2.3 \mathrm{E}-02$ & $1.5 \mathrm{E}-04$ & $\mathrm{ND}$ & $\mathrm{ND}$ \\
\hline
\end{tabular}

ND = Not determined.

The total amount of SL-644 initially added to the columns was $8.6 \mathrm{~g}$ (4.3 g/column) on a dry basis (at $95^{\circ} \mathrm{C}$ ) in the hydrogen form. When the resin was removed from the columns, it was in the sodium form in contact with dilute caustic $(<0.1 \mathrm{M} \mathrm{NaOH})$. The total volume of the resin beds just before removal from the columns was $40.7 \mathrm{~mL}$. This volume is expanded relative to the $30 \mathrm{~mL}$ of resin observed during the

a Information related to sample preparation may be found in the laboratory record book BNW 13687 , pages 19-22. Analytical results were obtained under Analytical Service Request \# 5732. 
loading step in the processing of the AW-101 sample and the $34.5 \mathrm{~mL}$ observed during the loading step in the processing of the $\mathrm{AN}-107$ sample.

\subsection{SL-644 Sample Preparation and Analyses}

The resin from both columns was removed into separate jars for removal from the hot cells. DI water from a squirt bottle was used to wash all of the resin from the columns. Excess liquid above the settled resin was removed with a syringe, but the resin remained submerged in liquid. Since some dilution of the interstitial liquid occurred, the concentration of $\mathrm{NaOH}$ was less than the $0.1 \mathrm{M}$ used to regenerate the columns in the last process step. Once the jars had been transferred to a fume hood, the contents were combined and manually mixed. The liquid in contact with the resin was a very dark, nearly opaque brown color.

Separate $10-\mathrm{mL}$ subsamples of the wet resin $(10.0262 \mathrm{~g})$ and the liquid were obtained in $20-\mathrm{mL}$ scintillation vials and counted directly for the GEA. The resin subsample was then dried at $95^{\circ} \mathrm{C}$ until a steady mass of $1.1532 \mathrm{~g}$ was obtained. The preparative method used to dissolve the resin was selected based on previous work with resin materials. The resin was dissolved on a best-effort basis, and no attempt was made to validate the preparative method for the analytes of interest. However, the method is considered to be applicable to the resin matrix and the analytes measured. In summary, the dried subsample was dissolved in hot nitric acid $(16 \mathrm{M})$ with the aid of hydrogen peroxide $(50 \%)$, taken to neardryness, and then diluted with water to a final volume of $20 \mathrm{~mL}$ with a nitric acid concentration of about $0.3 \mathrm{M}$. A flow diagram of the resin-preparation steps may be found in Appendix A. Separate 10-mL aliquots of the dissolved resin were used for ICP-AES following procedure PNNL-ALO-211 and ICP-MS following procedure PNNL-ALO-280. During the preparation of the wet resin subsample, excess liquid was removed from above the resin with a pipette, but the settled resin was kept in a fully submerged state. Consequently, the analytical results for the resin contain the contribution from the interstitial liquid.

Another portion of the SL-644 wet resin was air dried to a constant mass. Subsamples $(\approx 0.1 \mathrm{~g})$ of the air-dried resin were processed and diluted to a volume of $25 \mathrm{~mL}$ following digestion procedure PNNL-ALO-131. The mercury level was determined using CVAA spectroscopy following procedure PNNL-ALO-201. Separate subsamples of the air-dried resin were further dried in an oven at $95^{\circ} \mathrm{C}$ to determine the f-factor (ratio of oven-dried mass to air-dried mass). This information was used to adjust the mercury concentrations to a dry basis $\left(\right.$ at $\left.95^{\circ} \mathrm{C}\right)$.

\subsection{SL-639 Processing History}

The SL-639 was used in a small dual-column ion exchange system to remove Tc from samples of Tanks AW-101 and AN-107. Both samples had been previously processed for cesium removal with SL-644. The AW-101 sample was processed first in July 1999 (Blanchard et al. 1999), and this was followed about 16 weeks later in early November by processing the AN-107 sample (Blanchard et al. 2000). Following the processing of the AW-101 sample, the lead column was eluted with $0.5 \mathrm{M}$ nitric acid. The positions of the lead and lag columns were switched so that the partially loaded lag column 
became the lead column for the next sample. Following the processing of the AN-107 sample, the lead column was eluted with water at $\approx 50^{\circ} \mathrm{C}$. Some additional experimentation was completed in which some $\mathrm{AN}-107$ simulant was passed through the column and then some additional actual AN-107 sample. At the completion of these experiments, both columns were partially loaded so additional elution was conducted. Approximately $225 \mathrm{~mL}$ ( 48 bed volumes [BVs]) of DI water at $50^{\circ} \mathrm{C}$ was used to elute the first column. The initial $19 \mathrm{BVs}$ were pumped through the column at a flow rate of $3 \mathrm{BV} / \mathrm{h}$, and the remaining $29 \mathrm{BVs}$ were pumped at a rate of $1.5 \mathrm{BV} / \mathrm{h}$. The second column was eluted with $0.5 \mathrm{M}$ nitric acid at ambient temperature since switching the heating system to the second column would have been difficult. The volume of nitric acid used was about $363 \mathrm{~mL}$ (77 BVs). The flow rate was maintained at $3 \mathrm{BV} / \mathrm{h}$.

Several BVs of DI water were used to flush nitric acid from the system.

The extent to which Tc was removed from the columns before analysis is indicated in Table 2.2. The ${ }^{95} \mathrm{Tc} \mathrm{C} / \mathrm{C}_{0}$ value is shown for the final aliquot from each elution. The ${ }^{95} \mathrm{Tc}$ was added to the samples in trace amounts as ammonium pertechnetate $\left(\mathrm{NH}_{4} \mathrm{TcO}_{4}\right)$ in $1 \mathrm{M} \mathrm{NaOH}$ to follow the progress of the testing. The samples along with the original $\mathrm{AN}-107 \mathrm{Tc} \mathrm{IX}$ sample were counted in a portable GEA instrument. The $C_{0}$ value corresponds to the ${ }^{95} \mathrm{Tc}$ level found in the feed sample and was determined as counts per 3-min count time. For both columns, the desired elution cutoff of $\mathrm{C} / \mathrm{C}_{0}=1 \mathrm{E}-02$ was not obtained. This cutoff was also not obtained during the actual sample testing due to a very slow decline in $\mathrm{Tc}$ concentration that resulted in large volumes of eluate.

Table 2.2. Final ${ }^{95} \mathrm{Tc} \mathrm{C} / \mathrm{C}_{0}$ Values for the SL-639 Columns Used in Actual Waste Testing

\begin{tabular}{|c|c|c|}
\hline & Column 1 & Column 2 \\
\cline { 2 - 3 } & ${ }^{95}$ Tc C/C $\mathbf{C}_{0}$ & ${ }^{95}$ Tc C/C $C_{0}$ \\
\hline Final Eluate Sample & 0.053 & 0.036 \\
\hline
\end{tabular}

The total amount of SL-639 added to both columns was $9.4 \mathrm{~mL}$ or $4.5 \mathrm{~g}$ on a dry basis (at $95^{\circ} \mathrm{C}$ ). Unlike the SL-644, this material does not exhibit an appreciable change in volume when in contact with the various processing solutions. Consequently, the resin BV just before removal from the columns was unchanged.

\subsection{SL-639 Sample Preparation and Analyses}

The resin plus interstitial DI water from both columns was removed with a plastic bulb pipette and combined in a single container. After mixing, separate subsamples of the wet resin $(2.9321 \mathrm{~g}, 2.55 \mathrm{~mL})$ and the liquid $(1.9288 \mathrm{~g}, 2 \mathrm{~mL}$ ) were added to $20-\mathrm{mL}$ scintillation vials and counted directly for the GEA following procedure PNNL-ALO-450. The resin subsample was then dried at $95^{\circ} \mathrm{C}$ until a steady resin mass of $1.2251 \mathrm{~g}$ was obtained. The preparative method used to dissolve the resin by dry ashing and acid dissolution of the residue was selected based on previous work with resin materials. The resin was dissolved a best-effort basis, and no attempt was made to validate the preparative method for the analytes of interest. However, the method is considered to be applicable to the resin matrix and the analytes measured. In summary, the dried resin was ashed at $450^{\circ} \mathrm{C}$, and the ash was dissolved in $16 \mathrm{M}$ nitric acid 
on a hotplate, reduced in volume to $\approx 0.5 \mathrm{~mL}$, and then diluted with water to $20 \mathrm{~mL}$ with a nitric acid concentration of about $0.3 \mathrm{M}$. A flow diagram of the resin preparation steps may be found in Appendix A. Aliquots of this solution were used for ICP-AES following procedure PNNL-ALO-211 and ICP-MS following procedure PNNL-ALO-280. During the preparation of the wet resin subsample, excess liquid was removed from above the resin with a pipette, but the settled resin was kept in a fully submerged state. Consequently, the analytical results for the resin contain the contribution from the interstitial liquid.

Another portion of the SL-639 was air dried to a constant mass on filter paper. Subsamples $(\approx 0.1 \mathrm{~g})$ of the air-dried resin were processed and diluted to a volume of $25 \mathrm{~mL}$ per procedure PNNL-ALO-131. The mercury level was determined using CVAA spectroscopy following procedure PNNL-ALO-201. Separate subsamples of the air-dried resin were further dried in an oven at $95^{\circ} \mathrm{C}$ to determine the $\mathrm{f}$-factor (ratio of oven dried mass to air dried mass). This information was used to adjust the mercury concentrations to a dry basis (at $95^{\circ} \mathrm{C}$ ). 


\subsection{Results And Discusion}

This section contains the results of the analyses conducted on the SL-644 and SL-639 spent resin samples. The results of the analyses include ICP-AES (metals), CVAA (mercury), GEA (radionuclides) and ICP-MS (selected metals and radionuclides). The analytical reports and calculations may be found in Appendix B.

\subsection{ICP-AES Results}

The results of the analysis of the SL-644 and SL-639 spent resin samples with ICP-AES are shown in Table 3.1 along with the BNFL specified minimum reportable quantities (MRQs). Analytes of interest (i.e., those with specified MRQs) are given in the upper portion of the table while other analytes that were detected are given in the lower portion. All concentrations are based on the mass of the resin samples dried at $95^{\circ} \mathrm{C}$. The results for both samples contain the contribution from the interstitial liquid: $<0.1 \mathrm{M}$ $\mathrm{NaOH}$ for SL-644 and DI water for SL-639. The analytes of interest that were detected in the SL-644 sample at levels above the MRQs include $\mathrm{Cr}, \mathrm{K}$ and $\mathrm{Na}$. Potassium was the only analyte of interest detected in the SL-639 sample at levels above the MRQs. All specified MRQs were readily met and the quality control checks met the requirements of the governing quality assurance (QA) plan.

The results from Table 3.1 are given on a volume basis (10 mL for SL-644 and $2.55 \mathrm{~mL}$ for SL-639) in Table 3.2 and compared to the compositions of the cesium ion exchange (Cs IX) feeds. The compositions of the cesium ion exchange feeds were obtained from Kurath et al (1999) and Kurath et al (2000). The components that appear to have concentrated on the SL-644 resin relative to the feed concentrations include $\mathrm{Cr}, \mathrm{Co}$, and $\mathrm{Zr}$. Other metals that are found on the SL-644 resin in significant amounts include $\mathrm{Ca}, \mathrm{Cu}, \mathrm{Fe}, \mathrm{Na}, \mathrm{Ni}, \mathrm{Pb}, \mathrm{Sr}$, and $\mathrm{Zn}$. For SL-639, the only component that appears to be slightly concentrated relative to the feed is Fe. Other metals found on the SL-639 resin in significant amounts include $\mathrm{Cr}, \mathrm{Mn}, \mathrm{Na}$, and $\mathrm{Sr}$. The presence of these components indicates that the resins likely have some affinity for these metals. ${ }^{a}$ Processing of additional waste quantities or types, as will occur in the River Protection Project-Waste Treatment Plant (RPP-WTP), could result in higher levels of these metals in the resins. The high concentration of $\mathrm{Na}$ in the SL-644 resin is due to the resin being mainly in the sodium form and from the interstitial liquid. For both resin samples, a significant portion of the boron and silicon present is likely from leaching of the glassware used in the sample preparation.

\footnotetext{
${ }^{a}$ Results not contained in this report indicte that the SL-639 and SL-644 resins do not contain appreciable quantities of these components.
} 
Table 3.1. ICP-AES Analysis of Spent SL-644 and SL-639 Resins and the MRQs

\begin{tabular}{|c|c|c|c|}
\hline \multirow{2}{*}{$\begin{array}{c}\text { Analytes } \\
\text { of Interest }\end{array}$} & SL-644 & SL-639 & MRQ \\
\hline & $\mu \mathrm{g} / \mathrm{g}$ & $\mu \mathbf{g} / \mathbf{g}$ & $\mu \mathrm{g} / \mathrm{g}$ \\
\hline $\mathrm{Ag}$ & 5.04 & $<0.24$ & 100 \\
\hline $\mathrm{Al}$ & 60.9 & {$[6.5]$} & 3,600 \\
\hline $\mathrm{Ba}$ & {$[0.58]$} & {$[0.41]$} & 600 \\
\hline $\mathrm{Ca}$ & 147 & {$[9.9]$} & 6,000 \\
\hline $\mathrm{Cd}$ & {$[0.56]$} & $<0.24$ & 20 \\
\hline $\mathrm{Cr}$ & 669 & 5.0 & 100 \\
\hline $\mathrm{Cu}$ & 116 & {$[1.1]$} & 600 \\
\hline $\mathrm{Fe}$ & 84.2 & 30.4 & 1,200 \\
\hline $\mathrm{K}$ & {$[220]$} & {$[160]$} & 60 \\
\hline $\mathrm{La}$ & $<0.43$ & $<0.4$ & 3,000 \\
\hline $\mathrm{Mg}$ & {$[5.7]$} & [6.2] & 5,400 \\
\hline $\mathrm{Mn}$ & 0.92 & 1.63 & 300 \\
\hline $\mathrm{Na}$ & 83,800 & 2,300 & 5,400 \\
\hline $\mathrm{Ni}$ & 51.5 & {$[4.4]$} & 1,800 \\
\hline $\mathrm{Pb}$ & 10.9 & $<1$ & 30 \\
\hline $\mathrm{Ti}$ & 4.02 & {$[0.15]$} & 600 \\
\hline $\mathrm{Zn}$ & 20.6 & {$[0.45]$} & 1,200 \\
\hline \multicolumn{2}{|c|}{ Other Analytes Measured } & & \\
\hline As & $<1.4$ & [1.9] & -- \\
\hline $\mathrm{B}$ & 170 & 88.9 & -- \\
\hline $\mathrm{Bi}$ & {$[9.8]$} & $<1.6$ & -- \\
\hline $\mathrm{Co}$ & 70.9 & $<0.4$ & - \\
\hline $\mathrm{P}$ & {$[9.1]$} & {$[6.4]$} & - \\
\hline $\mathrm{Pd}$ & $<5.2$ & {$[6.9]$} & \\
\hline $\mathrm{Ru}$ & {$[1.4]$} & $<1.2$ & -- \\
\hline $\mathrm{Si}$ & 22.8 & 39.7 & - \\
\hline $\mathrm{Sr}$ & 1.57 & 2.4 & - \\
\hline Th & [14] & $<13$ & - \\
\hline $\mathrm{Zr}$ & 181 & $<0.4$ & -- \\
\hline
\end{tabular}

Notes:

1. Overall error for results greater than 10-times the method detection limit (MDL) is estimated to be $+/-15 \%$.

2. Results in brackets [ ] are within 10 times the MDL with errors likely to exceed $15 \%$.

3. Less than $(<)$ indicates the result is less than the MDL.

4. The dashes (-) indicate that no MRQ was specified.

5. The dissolution preparations (both wet ashing and dry ashing) were performed on a besteffort basis; i.e., dissolution procedures were not validated. 
Table 3.2. Comparison of ICP-AES Results for Spent SL-644 and SL-639 Resins to Cesium Ion Exchange Feed Concentrations

\begin{tabular}{|c|c|c|c|c|}
\hline $\begin{array}{l}\text { Analytes } \\
\text { of Interest }\end{array}$ & SL-644 & SL-639 & $\begin{array}{c}\text { AW-101 Cs IX } \\
\text { Feed }\end{array}$ & $\begin{array}{c}\text { AN-107 Cs IX } \\
\text { Feed } \\
\end{array}$ \\
\hline & $\mu \mathrm{g} / \mathrm{mL}$ & $\mu \mathrm{g} / \mathrm{mL}$ & $\mu \mathrm{g} / \mathbf{m L}$ & $\mu \mathrm{g} / \mathrm{mL}$ \\
\hline $\mathrm{Ag}$ & 0.58 & $<0.09$ & $<0.6$ & $<1$ \\
\hline $\mathrm{Al}$ & 7.0 & {$[3.1]$} & 11,100 & 2,450 \\
\hline $\mathrm{Ba}$ & {$[0.07]$} & {$[0.20]$} & $<0.4$ & $<0.4$ \\
\hline $\mathrm{Ca}$ & 17 & [4.8] & 5.6 & 170 \\
\hline $\mathrm{Cd}$. & {$[0.06]$} & $<0.09$ & 1.5 & 29 \\
\hline $\mathrm{Cr}$ & 77 & 2.4 & 43 & 46 \\
\hline $\mathrm{Cu}$ & 13 & {$[0.5]$} & 4.9 & 20 \\
\hline $\mathrm{Fe}$ & 9.7 & 14.6 & 14 & [11] \\
\hline $\mathrm{K}$ & {$[25]$} & {$[77]$} & 15,600 & {$[780]$} \\
\hline $\mathrm{La}$ & $<0.05$ & $<0.16$ & $<1$ & $<2$ \\
\hline $\mathrm{Mg}$ & {$[0.7]$} & {$[3.0]$} & $<4$ & $<4$ \\
\hline $\mathrm{Mn}$ & 0.106 & 0.78 & 1.6 & 2.9 \\
\hline $\mathrm{Na}$ & 9,660 & 1,100 & 105,500 & 119,200 \\
\hline $\mathrm{Ni}$ & 5.9 & [2.1] & 4.4 & 240 \\
\hline $\mathrm{Pb}$ & 1.3 & $<0.4$ & 27 & 67 \\
\hline $\mathrm{Ti}$ & 0.46 & {$[0.07]$} & $<0.2$ & $<1$ \\
\hline $\mathrm{Zn}$ & 2.4 & {$[0.22]$} & 5.2 & {$[6.7]$} \\
\hline \multicolumn{4}{|c|}{ Other Analytes Measured } & \\
\hline As & $<0.16$ & [0.9] & 18 & $<10$ \\
\hline $\mathrm{B}$ & 20 & 43.2 & 73 & 36 \\
\hline $\mathrm{Bi}$ & {$[1.1]$} & $<0.8$ & $<4$ & $<4$ \\
\hline Co & 8.2 & $<0.2$ & $<1$ & 2.5 \\
\hline $\mathrm{P}$ & {$[1.0]$} & {$[3.1]$} & 222 & 310 \\
\hline $\mathrm{Pd}$ & $<0.6$ & {$[3.3]$} & $<12$ & $<30$ \\
\hline $\mathrm{Ru}$ & {$[0.2]$} & $<0.6$ & $<3$ & $<45$ \\
\hline $\mathrm{Si}$ & 2.6 & 19.1 & 221 & {$[49]$} \\
\hline $\mathrm{Sr}$ & 0.18 & 1.16 & $<0.2$ & 136 \\
\hline $\mathrm{Th}$ & {$[2]$} & $<6.3$ & $<32$ & $<40$ \\
\hline $\mathrm{Zr}$ & 21 & $<0.2$ & 2.1 & 2.5 \\
\hline
\end{tabular}

\section{Notes:}

1. Overall error for results greater than 10 -times the MDL is estimated to be $+/-15 \%$.

2. Results in brackets [ ] are within 10 times the MDL with errors likely to exceed $15 \%$.

3. Less than $(<)$ indicates the result is less than the MDL.

4. The dissolution preparations (both wet ashing and dry ashing) were performed on a besteffort basis; i.e., dissolution procedures were not validated. 


\subsection{CVAA Results for Mercury}

The results of the analysis of the SL-644 and SL-639 spent-resin samples with CVAA for mercury are shown in Table 3.3 along with the BNFL-specified MRQ. The results are given on a mass basis and are based on the mass of the $\approx 0.1 \mathrm{~g}$ resin samples. The mass basis of the resin samples is adjusted to a dry basis at $95^{\circ} \mathrm{C}$ using f-factors (ratio of oven-dried mass to air-dried mass). The f-factor was 0.824 for SL-644 and 0.988 for SL-639. The results for both samples contain a minimal contribution from the interstitial liquid since most of the liquid was absorbed by the filter paper on which the samples were air dried. The MRQ was readily met for all samples. The level of mercury found in all of the resin samples is comparable to the levels found in the process blanks, so it appears that there is no appreciable quantity of mercury present in the resin samples.

In general, the quality control checks met the requirements of the governing QA plan with the exception of the matrix spike. The recovery of the matrix spike $(27 \%)$ was below the acceptance criteria of $75 \%$ to $125 \%$. The high-carbon content in the resin may have caused failure of the matrix spike by requiring more oxidizing reagent than was available. Recovery of the post spike was $105 \%$, well within the acceptance criteria of $75 \%$ to $125 \%$. Since the post-spike recovery was acceptable, it also implies that low recovery of the matrix spike was related to sample digestion.

Table 3.3. CVAA Mercury Analysis of Spent Resin and the MRQ

\begin{tabular}{|c|c|c|}
\hline Sample & Concentration & MRQ \\
\hline- & $\mu \mathrm{g} / \mathbf{g}$ & $\mu \mathrm{g} / \mathbf{g}$ \\
\hline SL-644 & 0.23 & 1.5 \\
\hline SL-639 & 0.13 & 1.5 \\
\hline process blank-1 & 0.19 & -- \\
\hline process blank-2 & 0.12 & -- \\
\hline
\end{tabular}

\subsection{Results of Gamma Energy Analysis}

The results of the GEA of the SL-644 and SL-639 spent resin samples are shown in Table 3.4 along with the BNFL specified MRQs. The results given on a mass basis $(\mu \mathrm{g} / \mathrm{g})$ in the second and third columns are based on the mass of the resin samples dried at $95^{\circ} \mathrm{C}$. The results given on a volume basis in columns 5 and 6 are based on the resin sample volumes; $10 \mathrm{~mL}$ for SL-644 and $2.55 \mathrm{~mL}$ for SL-639. The results for both samples contain the contribution from the interstitial liquid, which was $<0.1 \mathrm{M} \mathrm{NaOH}$ for SL-644 and DI water for SL-639. All specified MRQs were readily met, and the quality control checks met the requirements of the governing QA plan. The presence of ${ }^{95} \mathrm{Tc}$ and ${ }^{95 \mathrm{~m}} \mathrm{Tc}$ is the result of adding a ${ }^{95} \mathrm{Tc}$ tracer to the waste samples to monitor the Tc ion exchange experiment. The analytes of interest that were detected in the SL-644 sample at levels above the MRQs include ${ }^{60} \mathrm{Co}$ and ${ }^{137} \mathrm{Cs}$. No analytes of interest were found in the SL-639 sample at concentrations above the MRQs. 
Table 3.4. GEA Results for the Spent Resin and MRQs

\begin{tabular}{|c|c|c|c|c|c|}
\hline & SL-644 & SL-639 & MRQ & SL-644 & SL-639 \\
\cline { 2 - 6 } & $\mu \mathbf{C i} / \mathbf{g}$ & $\mu \mathbf{C i} / g$ & $\mu \mathbf{C i} / \mathbf{g}$ & $\mu \mathbf{C i} / \mathbf{m L}$ & $\mu \mathbf{C i} / \mathbf{m L}$ \\
\hline${ }^{60} \mathrm{Co}$ & $1.31 \mathrm{E}+00$ & $3.45 \mathrm{E}-04$ & $1.2 \mathrm{E}-01$ & $1.51 \mathrm{E}-01$ & $1.66 \mathrm{E}-04$ \\
\hline${ }^{137} \mathrm{Cs}$ & $2.13 \mathrm{E}+01$ & $7.5 \mathrm{E}-05$ & $1.0 \mathrm{E}-02$ & $2.46 \mathrm{E}+00$ & $3.6 \mathrm{E}-05$ \\
\hline${ }^{154} \mathrm{Eu}$ & $6.59 \mathrm{E}-03$ & $1.93 \mathrm{E}-03$ & $3.0 \mathrm{E}-01$ & $7.6 \mathrm{E}-04$ & $9.25 \mathrm{E}-04$ \\
\hline${ }^{155} \mathrm{Eu}$ & $1.43 \mathrm{E}-02$ & $1.83 \mathrm{E}-03$ & $6.0 \mathrm{E}+00$ & $1.65 \mathrm{E}-03$ & $8.78 \mathrm{E}-04$ \\
\hline & & & & & \\
\hline${ }^{125} \mathrm{Sb}$ & $<2.6 \mathrm{E}-02$ & $<3.3 \mathrm{E}-04$ & -- & $<3 \mathrm{E}-03$ & $<1.6 \mathrm{E}-04$ \\
\hline${ }^{134} \mathrm{Cs}$ & $1.64 \mathrm{E}-02$ & $<7.4 \mathrm{E}-05$ & -- & $1.89 \mathrm{E}-03$ & $<3.5 \mathrm{E}-05$ \\
\hline${ }^{144} \mathrm{CePr}$ & $<3.5 \mathrm{E}-02$ & $<8.0 \mathrm{E}-04$ & -- & $<4 \mathrm{E}-3$ & $<4 \mathrm{E}-04$ \\
\hline${ }^{241} \mathrm{Am}$ & $8.93 \mathrm{E}-03$ & $1.07 \mathrm{E}-03$ & -- & $1.03 \mathrm{E}-03$ & $5.13 \mathrm{E}-04$ \\
\hline${ }^{95} \mathrm{Tc}$ & -- & $2.64 \mathrm{E}-02$ & -- & -- & $1.27 \mathrm{E}-02$ \\
\hline${ }^{95 \mathrm{~m}} \mathrm{Tc}$ & -- & $5.58 \mathrm{E}-01$ & -- & -- & $2.68 \mathrm{E}-01$ \\
\hline
\end{tabular}

Note: -- indicates that no value was specified.

The results of the GEA of the interstitial liquid samples are shown in Table 3.5 along with the ratio of the concentrations (given as \%) in the liquid to the ratio of the concentrations in the resin plus liquid sample. These results are based on the liquid-sample volumes of $10 \mathrm{~mL}$ for the dilute caustic $(<0.1 \mathrm{M}$ $\mathrm{NaOH}$ ) in contact with the SL-644 resin and $2 \mathrm{~mL}$ for the DI water in contact with the SL-639. The relatively low-percentage values indicate that most of the radioactivity detected in the resin plus liquid samples was associated with the resin.

Table 3.5. Interstitial Liquid Radiochemical Results by Gamma Energy Analysis

\begin{tabular}{|c|c|c|c|c|}
\hline & SL-644 & $\begin{array}{c}\text { SL-644 } \\
\text { liquid:resin }\end{array}$ & SL-639 & $\begin{array}{c}\text { SL-639 } \\
\text { liquid:resin }\end{array}$ \\
\cline { 2 - 5 } & $\mu \mathbf{C i} / \mathbf{m L}$ & $\%$ & $\mu \mathbf{C i} / \mathbf{m L}$ & $\%$ \\
\hline${ }^{60} \mathrm{Co}$ & $8.2 \mathrm{E}-03$ & 5.4 & $<6 \mathrm{E}-06$ & 0 \\
\hline${ }^{137} \mathrm{Cs}$ & $1.6 \mathrm{E}-02$ & 0.65 & $<7 \mathrm{E}-06$ & 0 \\
\hline${ }^{154} \mathrm{Eu}$ & $1.4 \mathrm{E}-04$ & 17.9 & $6.3 \mathrm{E}-05$ & 8.5 \\
\hline${ }^{155} \mathrm{Eu}$ & $9.3 \mathrm{E}-05$ & 5.7 & $3.7 \mathrm{E}-05$ & 5.3 \\
\hline & & & & \\
\hline${ }^{125} \mathrm{Sb}$ & $5.0 \mathrm{E}-05$ & $\mathrm{ND}$ & $<2 \mathrm{E}-05$ & ND \\
\hline${ }^{134} \mathrm{Cs}$ & $2.3 \mathrm{E}-04$ & 12.2 & $<6 \mathrm{E}-06$ & ND \\
\hline${ }^{144} \mathrm{Ce}{ }^{144} \mathrm{Pr}$ & $6.1 \mathrm{E}-05$ & $\mathrm{ND}$ & $<4 \mathrm{E}-05$ & ND \\
\hline${ }^{241} \mathrm{Am}$ & $2.4 \mathrm{E}-04$ & 22.8 & $3.4 \mathrm{E}-05$ & 8.4 \\
\hline${ }^{95} \mathrm{Tc}$ & -- & ND & $2.1 \mathrm{E}-05$ & 0.21 \\
\hline${ }^{95 \mathrm{~m}} \mathrm{Tc}$ & -- & ND & $3.5 \mathrm{E}-04$ & 0.16 \\
\hline
\end{tabular}

Notes: -- indicates that no value was provided. $\mathrm{ND}=$ not determined because one or both values for ratio were at the MDL. 


\subsection{Results of ICP-MS Analyses}

The results of analyzing the SL-644 and SL-639 spent-resin samples with ICP-MS are shown in Table 3.6 along with the BNFL-specified MRQs. The results given on a mass basis $(\mu \mathrm{g} / \mathrm{g})$ in the second and third columns are based on the mass of the resin samples dried at $95^{\circ} \mathrm{C}$. The results given on a volume basis are based on the original volume of the resin samples; $10 \mathrm{~mL}$ for SL-644 and $2.55 \mathrm{~mL}$ for SL-639. The results contain the contribution from the interstitial liquid; $<0.1 \mathrm{M} \mathrm{NaOH}$ for SL-644 and DI water for SL-639. The analytes of interest that were detected in the SL-644 sample at levels above the MRQs include ${ }^{99} \mathrm{Tc}$ and ${ }^{238} \mathrm{U}$. For the SL-639 sample, only ${ }^{99} \mathrm{Tc}$ was detected at levels above the MRQs. All specified MRQs were readily met, and the quality control checks met the requirements of the governing QA plan.

Table 3.6. ICP-MS Analysis of Spent SL-644 Resin and the Minimum Reportable Quantities

\begin{tabular}{|c|c|c|c|c|c|}
\hline & SL-644 & SL-639 & MRQ & SL-644 & SL-639 \\
\hline & $\mu \mathrm{g} / \mathrm{g}$ & $\mu \mathrm{g} / \mathrm{g}$ & $\mu \mathrm{g} / \mathrm{g}$ & $\mu \mathrm{g} / \mathrm{mL}$ & $\mu \mathrm{g} / \mathrm{mL}$ \\
\hline$\overline{\text { As }}$ & $2.86 \mathrm{E}-01$ & $2.13 \mathrm{E}+00$ & $2.3 \mathrm{E}+00$ & $3.3 \mathrm{E}-02$ & $1.02 \mathrm{E}+00$ \\
\hline $\mathrm{Se}$ & $<6.3 \mathrm{E}-02$ & $6.7 \mathrm{E}-02$ & $2.0 \mathrm{E}+01$ & $<7.3 \mathrm{E}-03$ & $3.2 \mathrm{E}-02$ \\
\hline $\mathrm{Tl}$ & $1.87 \mathrm{E}-01$ & $<5.4 \mathrm{E}-03$ & $6.0 \mathrm{E}+00$ & $2.2 \mathrm{E}-02$ & $<2.6 \mathrm{E}-03$ \\
\hline $\mathrm{V}$ & $9.3 \mathrm{E}-02$ & $1.36 \mathrm{E}-02$ & $6.0 \mathrm{E}+00$ & $1.1 \mathrm{E}-02$ & $6.5 \mathrm{E}-03$ \\
\hline${ }^{99} \mathrm{Tc}$ & $6.74 \mathrm{E}+00$ & $6.95 \mathrm{E}+00$ & $2.0 \mathrm{E}+00$ & $7.8 \mathrm{E}-01$ & $3.34 \mathrm{E}+00$ \\
\hline${ }^{126} \mathrm{Sn}^{(1)}$ & $1.2 \mathrm{E}-02$ & $<2.2 \mathrm{E}-03$ & $6.0 \mathrm{E}+00$ & $1.4 \mathrm{E}-03$ & $<1 \mathrm{E}-03$ \\
\hline${ }^{127} I$ & $2.0 \mathrm{E}-02$ & $<8.6 \mathrm{E}-03$ & $3.0 \mathrm{E}+01$ & $2.0 \mathrm{E}-03$ & $<4.1 \mathrm{E}-03$ \\
\hline${ }^{129} \mathrm{I}$ & $<4.7 \mathrm{E}-03$ & $3.3 \mathrm{E}-03$ & - & $<5 \mathrm{E}-04$ & $1.6 \mathrm{E}-03$ \\
\hline${ }^{233} \mathrm{U}$ & $<5.2 \mathrm{E}-03$ & $<2 \mathrm{E}-03$ & $6.0 \mathrm{E}-01$ & $<6 \mathrm{E}-04$ & $<1 \mathrm{E}-03$ \\
\hline${ }^{234} \mathrm{U}$ & $<2.6 \mathrm{E}-03$ & $<1 \mathrm{E}-03$ & $6.0 \mathrm{E}+00$ & $<3 \mathrm{E}-04$ & $<5 \mathrm{E}-04$ \\
\hline${ }^{235} \mathrm{U}$ & 1.52E-01 & $<2 \mathrm{E}-03$ & $6.0 \mathrm{E}+00$ & $1.8 \mathrm{E}-02$ & $<1 \mathrm{E}-03$ \\
\hline${ }^{236} \mathrm{U}$ & $1.5 \mathrm{E}-02$ & $<2 \mathrm{E}-03$ & $6.0 \mathrm{E}+00$ & $1.7 \mathrm{E}-03$ & $<1 \mathrm{E}-03$ \\
\hline${ }^{238} \mathrm{U}$ & $1.48 \mathrm{E}+01$ & $2.1 \mathrm{E}-02$ & $6.0 \mathrm{E}+00$ & $1.71 \mathrm{E}+00$ & $1.0 \mathrm{E}-02$ \\
\hline${ }^{237} \mathrm{~Np}$ & $4.7 \mathrm{E}-02$ & $<2.2 \mathrm{E}-03$ & $6.0 \mathrm{E}+00$ & $5.4 \mathrm{E}-03$ & $<1.1 \mathrm{E}-03$ \\
\hline${ }^{239} \mathrm{Pu}$ & $6.6 \mathrm{E}-02$ & $<2 \mathrm{E}-03$ & $6.0 \mathrm{E}+00$ & $7.7 \mathrm{E}-03$ & $<1 \mathrm{E}-03$ \\
\hline${ }^{240} \mathrm{Pu}(1)$ & $1.4 \mathrm{E}-02$ & $<2 \mathrm{E}-03$ & $6.0 \mathrm{E}+00$ & $1.6 \mathrm{E}-03$ & $<1 \mathrm{E}-03$ \\
\hline${ }^{241} \mathrm{AMU}^{(2)}$ & $<5.2 \mathrm{E}-03$ & $<2 \mathrm{E}-03$ & TBD by method & $<6 \mathrm{E}-04$ & $<1 \mathrm{E}-03$ \\
\hline${ }^{242} \mathrm{AMU}^{(2)}$ & $<5.2 \mathrm{E}-03$ & $<2 \mathrm{E}-03$ & TBD by method & $<6 \mathrm{E}-04$ & $<1 \mathrm{E}-03$ \\
\hline${ }^{243} \mathrm{AMU}^{(2)}$ & $<5.2 \mathrm{E}-03$ & $<2 \mathrm{E}-03$ & TBD by method & $<6 \mathrm{E}-04$ & $<1 \mathrm{E}-03$ \\
\hline
\end{tabular}

(1) Calculated from response of different isotope. Results should be considered semiquantitative.

(2) AMU-242 calculated using Pu-242. AMU-241,243 calculated using Am-241, Am-243. 


\subsection{Conclusions}

The following conclusions can be drawn from these studies.

- The analytes of interest that were above the MRQs for the SL-644 resin include $\mathrm{Cr}, \mathrm{K}, \mathrm{Na},{ }^{60} \mathrm{Co},{ }^{99} \mathrm{Tc}$, ${ }^{137} \mathrm{Cs}$, and ${ }^{238} \mathrm{U}$.

- The analytes of interest that were above the MRQs for the SL-639 resin include K and ${ }^{99} \mathrm{Tc}$.

- Based on the ICP-AES results, the components that appear to have concentrated (relative to the waste samples processed) on the SL-644 include Cr, Co, and Zr. For the SL-639 resin, the only component that appears to be slightly concentrated is Fe. The presence of these components indicates that the resins likely have some affinity for these metals.

- No significant level of mercury was found in either of the Superlig samples.

- The analytical methods met the MRQs for all analytes of interest. 


\subsection{References}

Blanchard, DL, Jr, DE Kurath, and JR Bontha. 1999. Small Column Testing of Superlig 639 for Removal of ${ }^{99}$ Tc from Hanford Tank Waste Envelope A (Tank 241-AW-101), BNFL-RPT-016, PNWD-3004, Battelle Pacific Northwest Division, Richland, Washington.

Blanchard, DL, Jr, DE Kurath, and BM Rapko. 2000. Small Column Testing of Superlig 639 for Removal of ${ }^{99}$ Tc from Hanford Tank Waste Envelope C (Tank 241-AN-107), BNFL-RPT-022, PNWD3028, Battelle Pacific Northwest Division, Richland, Washington.

Kurath, DE, DL Blanchard, Jr, and JR Bontha. 1999. Small Column Ion Exchange Testing of Superlig 644 for Removal of ${ }^{137} \mathrm{Cs}$ from Hanford Tank Waste Envelope A (Tank 241-AW-10), BNFL-RPT-014, PNWD-3001, Battelle Pacific Northwest Division, Richland, Washington.

Kurath, DE, DL Blanchard, Jr, and JR Bontha. 2000. Small Column Ion Exchange Testing of Superlig 644 for Removal of ${ }^{137}$ Cs from Hanford Tank Waste Envelope C (Tank 241-AN-107), BNFL-RPT-024, PNWD-3039, Battelle Pacific Northwest Division, Richland, Washington. 
Appendix A

Resin Sample Preparation Flow Diagrams 


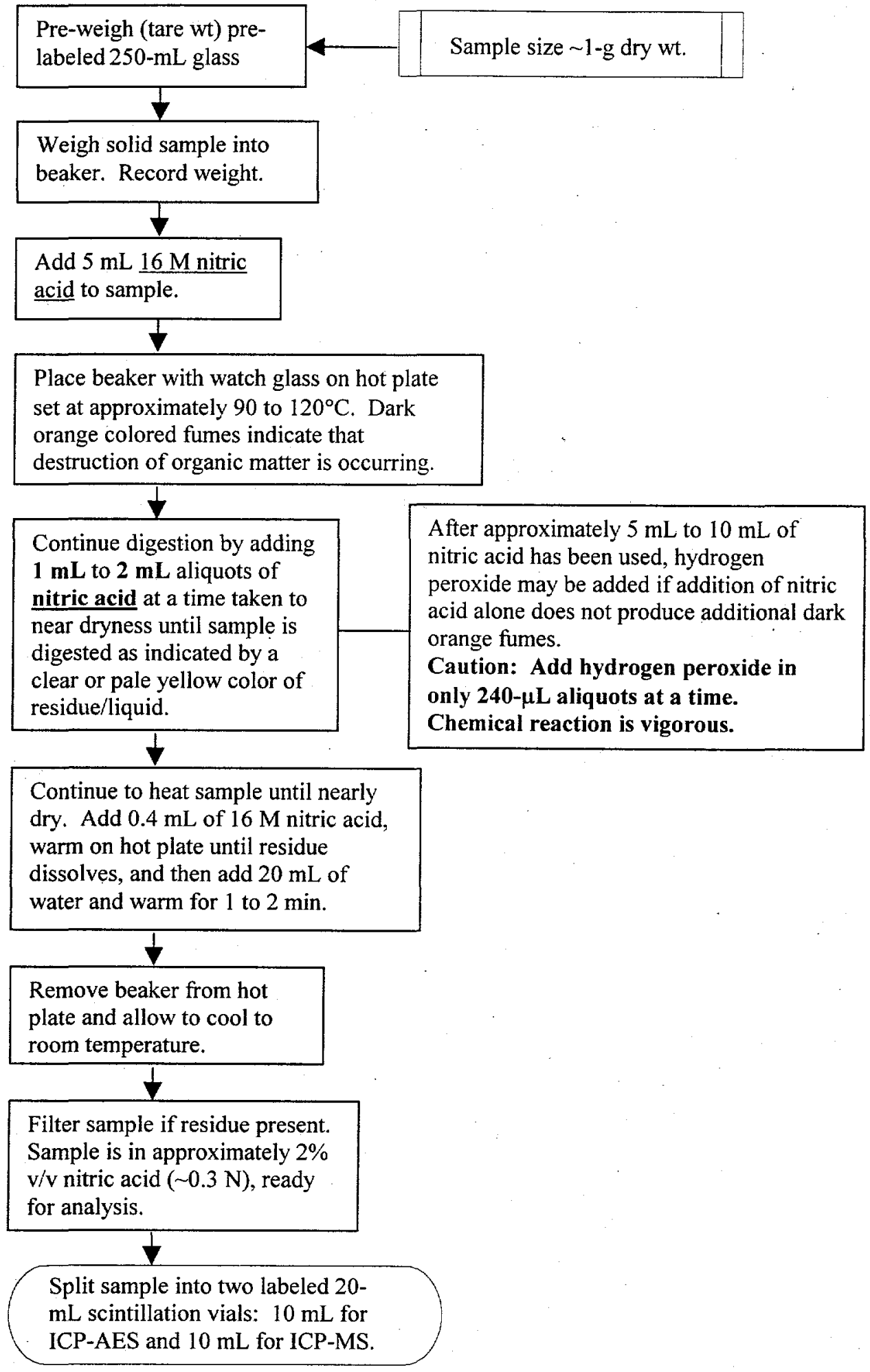

Figure A.1. Flowsheet for Analytical Preparation of SL-644 


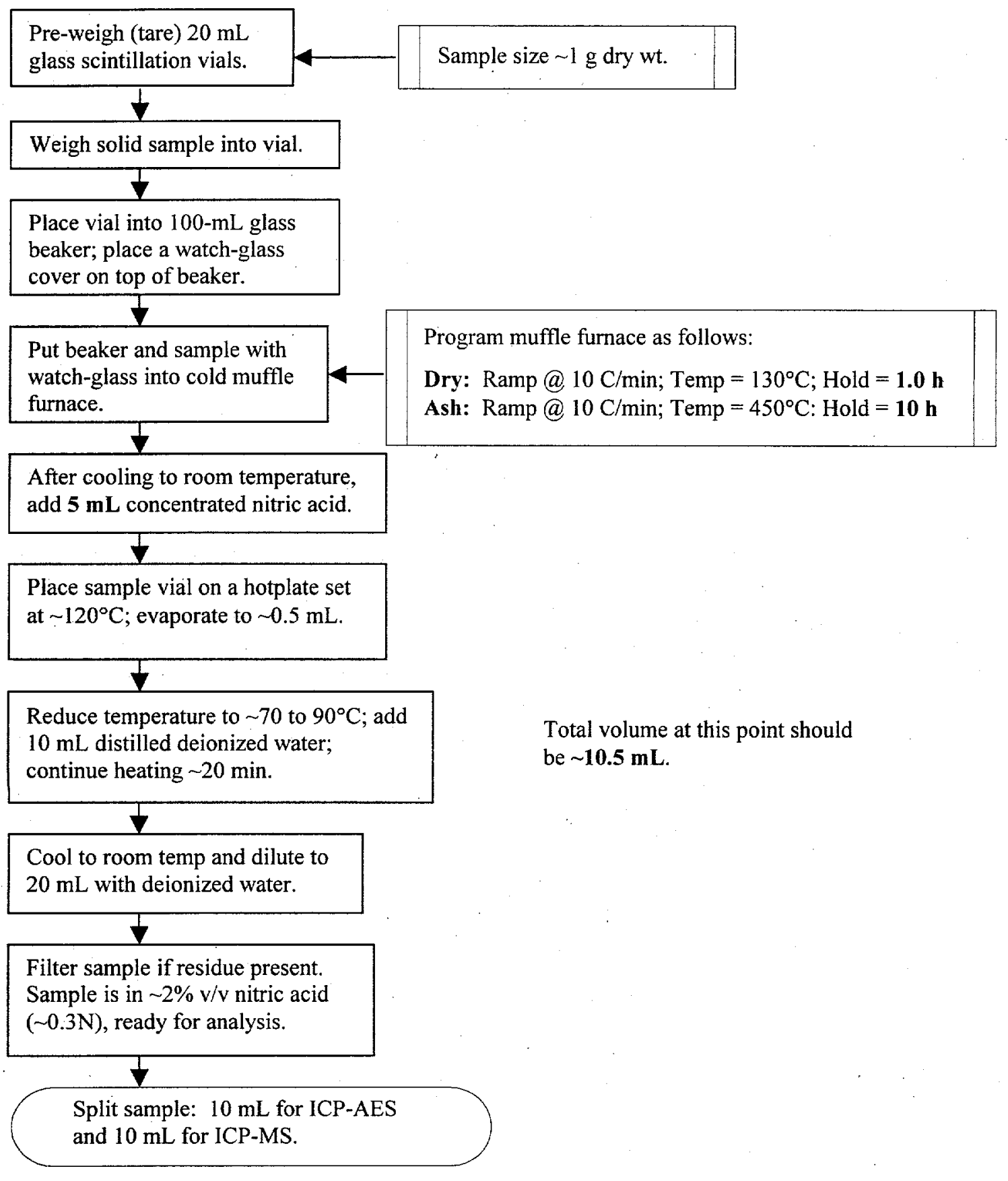

Figure A.2. Flow sheet for Analytical Preparation of SL-639 
Appendix B

Analytical Results and Analysis 


\section{Sample Identification}

\begin{tabular}{|c|c|l|}
\hline Sample ID & Sample Number & \multicolumn{1}{c|}{ Description } \\
\hline SL-644-SR & $00-1367$ & SL-644 resin sample + interstitial liquid \\
\hline SL-639-SR & $00-1368$ & SL-639 resin sample + interstitial liquid \\
\hline SL-644-LQ & $00-1369$ & $\begin{array}{l}\text { Interstitial liquid in contact with the SL-644 resin sample } \\
(<0.1 \mathrm{M} \mathrm{NaOH)}\end{array}$ \\
\hline SL-639-LQ & $00-1370$ & $\begin{array}{l}\text { Interstitial liquid in contact with the SL-639 resin sample } \\
\text { (DI water) }\end{array}$ \\
\hline
\end{tabular}

Note: 1) Analytical Service Request \# 5732

B. 1 


\section{Battelle PNNL/RPG/Inorganic Analysis ... ICPAES Data Report}

Project: 29953

Client:

D. Kurath

RPL Number(s): 00-01367 \& 00-01368

Client ID: "SL-644-SR" through "SL-639-SR"

ASR Number: 5732

Total Samples: 2

Procedure: PNL-ALO-211, "Determination of Elements by Inductively Coupled Argon Plasma Atomic Emission Spectrometry" (ICP-AES).

Analyst: D.R. Sanders

Analysis Date (Filename): $\quad 03-15-00$ (A0589)

See Chemical Measurement Center 98620: ICP-325-405-1 File for Calibration and Maintenance Records.

M\&TE Number: $\quad$ ICPAES instrument -- WB73520

Mettler AT400 Balance -- Ser.No. 360-06-01-029
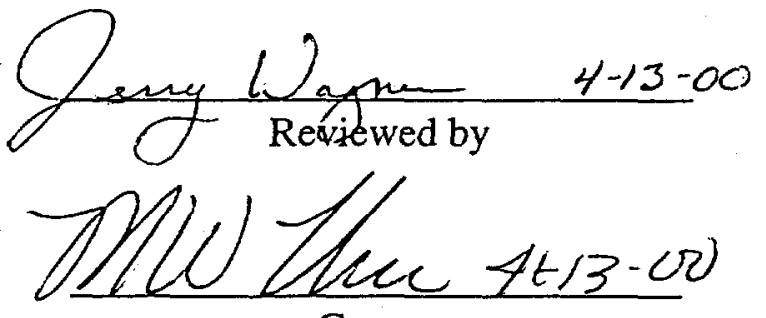

Concur

$\underline{4 / 13 / 00}$ 


\section{Battelle PNNL/RPG/Inorganic Analysis ... ICPAES Data Report}

Spent ion exchange resin sample SL-644-SR (RPL\# 00-01367) and process blank was prepared using a wet-ash procedure prior to ICPAES and ICP-MS analysis. About $1.1532 \mathrm{~g}$ of oven dried $\left(95^{\circ} \mathrm{C}\right)$ spent ion exchange resin was processed using nitric acid and hydrogen peroxide in glass beakers and diluted to a final volume of $20 \mathrm{ml}$. See attached sample processing flow diagram and description of wet-ash procedure below.

Spent ion exchange resin sample SL-639-SR (RPL\# 00-01368) and process blank was prepared using a dry-ash procedure prior to ICPAES and ICP-MS analysis. About $1.2251 \mathrm{~g}$ of oven dried $\left(95^{\circ} \mathrm{C}\right)$ spent ion exchange resin was processed using nitric acid in glass scintillation vials and diluted to a final volume of $20 \mathrm{ml}$. . See attached sample processing flow diagram and description of dry-ash procedure below.

Wet-ash procedure:

The spent ion exchange resin sample SL-644-SR was transferred from the 20cc scintillation vial that it was dried in, to a $250-\mathrm{ml}$ glass beaker using about $25 \mathrm{ml}$ of water and several $1 \mathrm{ml}$ aliquots of $16 \mathrm{M}$ nitric acid. After the sample was transferred to the beaker a watch glass was placed on the beaker and the beaker placed on a small 4" $\mathrm{6} 6$ " Corning hot plate (temp. knob set to about " 3 "). As soon as the mixture got hot $\left(90\right.$ to $120^{\circ} \mathrm{C}$ ), dark orange colored NOx fumes and foam appeared. A separate process blank was prepared similarly to the sample. All reagents used on the sample were included in the process blank. The sample and a process blank were brought to a rapid boil and allowed to evaporate over a period of about two hours. When the sample and acid evaporated to near dryness, dark orange fumes again began to appear. Small one to two $\mathrm{ml}$ aliquots of $16 \mathrm{M} \mathrm{HNO} 3$ were added to the boiling mixture over a half-hour time period. Since no additional dark orange fumes appeared, $0.25 \mathrm{ml}$ of $30 \%$ hydrogen peroxide was added to the hot mixture. A vigorous reaction began along with foaming in the glass beaker in which the foam went about one-third the way up the wall. Several additional aliquots $(0.25 \mathrm{ml})$ of hydrogen peroxide were added. Shortly afterward the foam subsided the mixture was allowed to evaporate to near dryness. Foam was still present when the mixture was near dryness. About $0.25 \mathrm{ml}$ of hydrogen peroxide was added at this time. As soon as the peroxide contacted the mixture a rapid reaction occurred in which the residue in the beaker turned from an orangeyellow color to a dark mixture of fine black particles like carbon. Ten ml of $16 \mathrm{M}$ nitric acid was immediately added to the mixture and the hot plate temperature reduced to "low" position. The heated mixture continuously produced small bubbles and after about 15 minutes some clearing could be seen. The mixture was allowed to remain on the hot plate set at "low" over night. The next morning the mixture had evaporated to near dryness with a very small amount of dark particles remaining. About $0.4 \mathrm{ml}$ of $16 \mathrm{M}$ nitric acid and $18.6 \mathrm{ml}$ of water was added to the sample and blank and warmed on the hot plate for about 10 minutes on "low" setting. The process blank and sample was allowed to cool to room temperature then filtered using a $47 \mathrm{~mm}$ diameter $0.45 \mathrm{~nm}$ nitrocellulose membrane filter. Ten $\mathrm{ml}$ of process blank and sample filtrate

$\underline{4 / 13 / 00}$ 


\section{Battelle PNNL/RPG/Inorganic Analysis ... ICPAES Data Report}

was placed in separate pre-cleaned and labeled scintillation vials marked for ICP-MS analysis. Similarly, the remaining filtered process blank and sample was placed in pre-cleaned and labeled scintillation vials marked for ICPAES analysis. Because the samples were prepared in glass beakers, boron, silicon and sodium are likely to present in both the blank and sample solutions.

\section{Dry-ash procedure:}

The spent ion exchange resin sample SL-639-SR was processed in the same 20cc glass scintillation vial that was used for drying the resin. The glass scintillation vial containing the oven-dried resin sample was placed inside a 100 -ml glass beaker with a watch glass on top of the beaker. A second pre-cleaned, glass scintillation vial, used for the process blank, was placed inside a $100 \mathrm{ml}$ glass beaker with a watch glass on top of the beaker. Both beakers with sample and process blank vials were placed in a cold (room temperature) programmable muffle furnace. The muffle furnace temperature ramp-rate, hold-temperature and hold-time was programmed as follows. The dry cycle was set for a ramp-rate of $10^{\circ} \mathrm{C} /$ minute; hold-temperature of $130^{\circ} \mathrm{C}$; and hold-time of 1 hour. The ash cycle was set for a ramp-rate of $10^{\circ} \mathrm{C} /$ minute; hold-temperature of $450^{\circ} \mathrm{C}$; and hold-time of 10 hours. After the furnace cooled to about $100^{\circ} \mathrm{C}$ the beakers with vials were removed and set aside to cool to room temperature. Only a small amount of gray-ash (less than approximately $50 \mathrm{mg}$ ) remained in the vial that originally held the resin. About $5 \mathrm{ml}$ of $16 \mathrm{M}$ nitric acid was added to the ash residue and also process blank scintillation vials (scintillation vials still in $100 \mathrm{ml}$ beakers). The $100 \mathrm{ml}$ beakers with sample and process blank vials place on a small 4 " $\times 6$ " Corning hot plate set to about $120^{\circ} \mathrm{C}$. The sample and process blank liquid was allowed to evaporate to about $0.5 \mathrm{ml}$. The hot plate temperature was reduced to about 70 to $90^{\circ} \mathrm{C}$ and about $10 \mathrm{ml}$ of water was added and allowed to continue heating for about 20 minutes. The sample and blank solutions were removed from the hot plate and allowed to cool to room temperature. Water was added to bring the final volume to $20 \mathrm{ml}$. The entire sample appeared to be dissolved. No noticeable residue remained after diluting to volume. The final solutions were approximately $0.3 \mathrm{M}$ in nitric acid. Ten ml of sample and blank were transferred to separate pre-cleaned scintillation vials labeled for ICP-MS analysis. The remaining $10 \mathrm{ml}$ of sample and process blank was labeled for ICPAES analysis. Because the samples were prepared in $20 \mathrm{cc}$ glass scintillation vials, boron, silicon and sodium are likely to present in both the blank and sample solutions.

Analytes of interest include: $\mathrm{Al}, \mathrm{Ag}, \mathrm{Ba}, \mathrm{Ca}, \mathrm{Cd}, \mathrm{Cr}, \mathrm{Cu}, \mathrm{Fe}, \mathrm{K}, \mathrm{La}, \mathrm{Mg}, \mathrm{Mn}, \mathrm{Na}, \mathrm{Ni}, \mathrm{Pb}, \mathrm{Ti}$, and $\mathrm{Zn}$. Reference, Table 1 "Anlaysis of Dissolved Ion Exchange Resins". MRQ's for all analytes of interest were met. Many of the analytes of interest were detected in both resin samples. Sample SL-644-SR generally had higher concentrations of similar analytes than sample SL-639-SR. All ICPAES measurement results are reported in $\mu \mathrm{g} / \mathrm{g}$ dry weight of spent ion exchange resin and have been corrected for processing and analytical dilution. 


\section{Battelle PNNL/RPG/Inorganic Analysis ... ICPAES Data Report}

Quality control check-standard results met tolerance requirements for all analytes except as noted . below. Following is a list of quality control measurement results relative to ICPAES analysis tolerance requirements

Five fold serial dilution:

(Solid samples)

Results were within tolerance limit of $\leq 10 \%$ for all analytes tested after correcting for dilution except for nickel in sample SL-644-SR. Nickel concentration after dilution correction was slightly above the $10 \%$ limit $(10.7 \%)$. Other analyte results above EQL were well within tolerance limit. The reason for the slightly high result is not known.

Duplicate RPD (Relative Percent Difference):

(Solid samples) Duplicate RPD was not tested because of limit sample material available.

Post-Spiked Samples (Group A):

(Solid samples)

All analytes of interest were recovered within tolerance limit of $75 \%$ to $125 \%$.

Post-Spiked Samples (Group B):

(Solid samples)

All analytes of interest were recovered within tolerance of $75 \%$ to $125 \%$.

Blank Spike:

(Solid samples) A blank spike was not prepared.

Matrix Spiked Sample:

(Solid samples)

A matrix spike is was not prepared due to insufficient sample material.

Quality Control Check Standards (solid samples):

Concentration of all analytes of interest was within tolerance limit of $\pm 10 \%$ accuracy in standards: QC_MCVA, QC_MCVB, and QC_SSTMCV. Calibration Blank (ICP98.0) concentration was acceptable, less than two times IDL.

High Calibration Standard Check (solid samples):

Verification of the high-end calibration for all analytes was within tolerance limits of $\pm 5 \%$ accuracy.

$4 / 13 / 00$ 


\section{Battelle PNNL/RPG/Inorganic Analysis ... ICPAES Data Report}

Process Blank:

(solid samples)

All analytes of interest were within tolerance limit of $\leq \mathrm{EQL}$ or $<5 \%$ of sample concentration in the prepared samples. Sodium was the only analyte of interest measured in the process blank that was above EQL $(16.3 \mathrm{ug} / \mathrm{g})$. However, sodium in the process blank was less than $2 \%$ of the concentration in sample SL-639-SR and less than $0.1 \%$ of the concentration in sample SL-644-SR.

Laboratory Control Standard (LCS):

(Solid samples) An LCS sample was not prepared.

Please note bracketed values listed in the data report are within ten times instrument detection limit and have a potential uncertainty much greater than $15 \%$.

Comments:

1) "Final Results" have been corrected for all laboratory dilution performed on the sample during processing and analysis unless specifically noted.

2) Detection limits (DL) shown are for acidified water. Detection limits for other matrices may be determined if requested.

3) Routine precision and bias is typically $\pm 15 \%$ or better for samples in dilute, acidified water (e.g. $2 \% \mathrm{v} / \mathrm{v} \mathrm{HNO}_{3}$ or less) at analyte concentrations greater than ten times detection limit up to the upper calibration level. This also presumes that the total dissolved solids concentration in the sample is less than $5000 \mu \mathrm{g} / \mathrm{mL}(0.5$ per cent by weight $)$.

4) Absolute precision, bias and detection limits may be determined on each sample if required by the client.

5) The maximum number of significant figures for all ICP measurements is 2. 


\section{Battelle PNNL/RPG/Inorganic Analysis ... ICPAES Data Report Page 1 of 1}



- Data (1) Irom 'A0589 S. Fiskum ASR-5600, D.Kurath ASR-5732, J.Wagner Siemens pre-process verilication, Ytrium_Na-Zr evaluation ICP98 low.XLS 
WO/Project: · W45529/29953

Client: D. Kurath

ACL Numbers: 00-01367 \& 00-01368

ASR Number 5732

Procedure: PNNL-ALO-131, "Mercury Digestion"

PNNL-ALO-201, "Mercury Analysis"

Analyst: J. J. Wagner

Digestion Date: March 14, 2000 Analysis Date: March 15, 2000

M\&TE: Hg system (WD14126); Mettler AT400 Balance (360-06-01-029) See Chemical Measurement Center 98620 RIDS for Hg File for Calibration, Standards Preparations, and Maintenance Records.

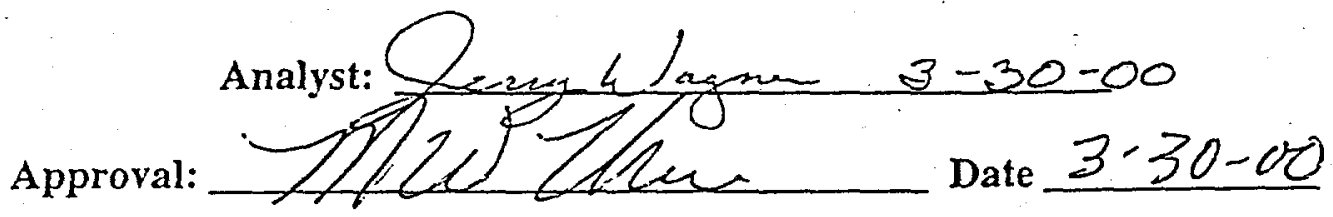

Final Results:

The samples were analyzed by cold vapor atomic absorption spectrophotometry for inorganic mercury as specified in ASR 5732. Approximately $0.1 \mathrm{~g}$ dry sample weight was processed and diluted to a final volume of $25 \mathrm{ml}$ per procedure ALO-131. No additional dilution was performed. The mercury concentration results are presented in the table below. 


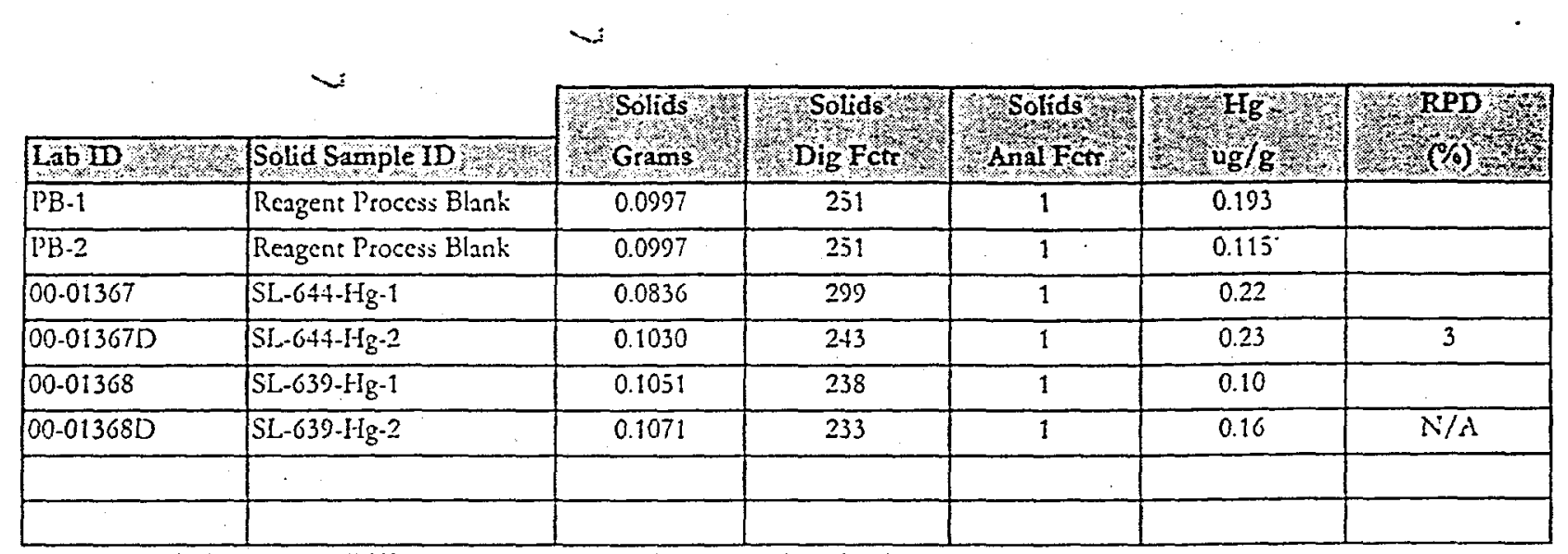

RPD $=$ Relative Percent Difference (between sample and duplicate/replicate)

"Sample weight" used for the process blank is an average weight of the samples.

$N / A=R P D$ is not calculated when results are less than $5 \times$ IDL

\section{Notes:}

1) "Final Results" have been corrected for all dilution performed on the sample during processing or analysis.

2) The low calibration standard is defined as the estimated detection limit (IDL) for the reported results and assumes non-complex aqueous matrices. Actual detection limits or quantitation limits for specific sample matrices may be determined, if requested.

3) Routine precision and bias is typically $\pm 15 \%$ or better for non-complex aqueous samples that are free of interference.

\section{Q.C. Comments:}

Following are results of quality control checks performed during $\mathrm{Hg}$ analyses. In general, quality control checks met the requirements of the governing QA Plan.

Working Blank Spike/Process Blank Spike: Process Blank Spike recovery is $96 \%$ and $95 \%$, well within the acceptance criteria of $80 \%$ to $120 \%$.

Matrix Spiked Sample: A matrix spike was prepared for the samples submitted under this ASR. However, recovery of the matrix spike $(27 \%)$ fell below the acceptance criteria of $75 \%$ to $125 \%$. The high carbon content in the resin may have caused failure of the matrix spike by requiring more oxidizing reagent than was available. Recovery of a post-spike for that sample was $105 \%$, well within the acceptance criteria of $75 \%$ to $125 \%$. Since the post-spike recovery was acceptable it also implies that low recovery of the matrix spike was related to sample digestion. Duplicate: Relative percent difference for the duplicate samples is within acceptance criteria of $\leq 20 \%$ RPD for RPL 00-01367 and 00-1367D (3\% RPD).

Laboratory Control Sample (solids): Sample recovery of mercury in SRM-2709 San Joaquin Valley Soil certified by NIST to contain $1.40 \pm 0.08 \mu \mathrm{g} / \mathrm{g}$ was recovered within acceptance criteria of $75 \%$ to $125 \%$. 
System Blank/Processing Blanks: A system blank was process during the analysis of the sample. The concentration measured was within about two times detection limit or less. Some samples were about the same concentration as the process blank and other samples were many times this level.

Quality Control Calibration Verification Check Standards: Six mid-range verification standards were analyzed throughout the analysis run. All were within the acceptance criteria of $80 \%$ to $120 \%$ recovery for the verification standard. 
Internal Distribution

$329 / 4$ File

Date $\quad$ April 7, 2000

LSO Project File

Jerry. Wagner

To Dean Kurath

From Tom Farmer C J Jamen 7AproO

Subject ICP/MS Analysis of Submitted Samples

(ALO\#00-001367 and 00-001368)

Pursuant to your request, the 4 samples that you submitted for analysis were analyzed by ICPMS for selected elements. The results of this analysis are reported on the attached pages. Both the method detection limit values, as listed on ASR \#5732, and the ICP/MS analyzed values have been provided.

Single element $\mathrm{CPI}$ standards for $\mathrm{V}, \mathrm{As}, \mathrm{Sn}, \mathrm{TI}$ and Se, an NIST uranium standard (4321B), an Amersham ${ }^{99} \mathrm{Tc}$ standard, Isotope Products standards for ${ }^{129} /,{ }^{239} \mathrm{Pu},{ }^{233} \mathrm{U}$ ${ }^{242} \mathrm{Pu}{ }^{241} \mathrm{Am}{ }^{243} \mathrm{Am}$ and ${ }^{237} \mathrm{~Np}$ and an ${ }^{127} \mathrm{I}$ standard, prepared from Fisher potassium iodide (LOT\# 35260) were used to generate the calibration curves. Independent standards of each element were used as the continuing calibration verification (CCV) standards.

The ${ }^{99} \mathrm{Tc}$ values reported assume that the Ru present is exclusively fission-product $R u$, and therefore does not have an isotope at $\mathrm{m} / \mathrm{z} 99$; i.e., everything observed at $\mathrm{m} / \mathrm{z} 99$ is due to ${ }^{99} \mathrm{Tc}$. The fingerprint we're seeing for $\mathrm{Ru}$ is obviously not natural, and is consistent with that observed in previous tank waste analyses.

Interference corrections were performed on ${ }^{129}$ (xenon corrected), ${ }^{239} \mathrm{Pu}$ (uranium hydride corrected), ${ }^{126} \mathrm{~S}$ ! (tellurium and xenon corrected).

Values for the following isotopes were obtained using responses from related isotopes: ${ }^{240} \mathrm{Pu}$ (obtained from ${ }^{239} \mathrm{Pu}$ ), AMU-241, 243 were obtained from ${ }^{241} \mathrm{Am}$ and ${ }^{243} \mathrm{Am}$ and AMU-242 was obtained from ${ }^{242} \mathrm{Pu}$.

If you have any questions regarding this analysis, feel free to call me at 372-0700 or James Bramson at 372-0624

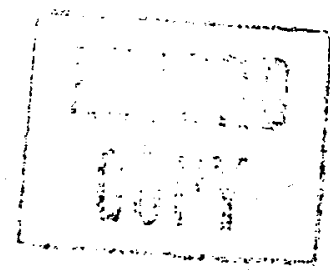

$$
\begin{aligned}
& \text { Praj } 29953 \\
& T 2.10,4 \\
& \text { Tosb } 10
\end{aligned}
$$


Dean Kurath Analysis

April 7, 2000

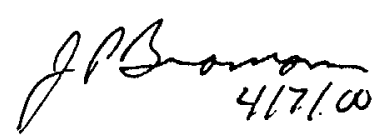

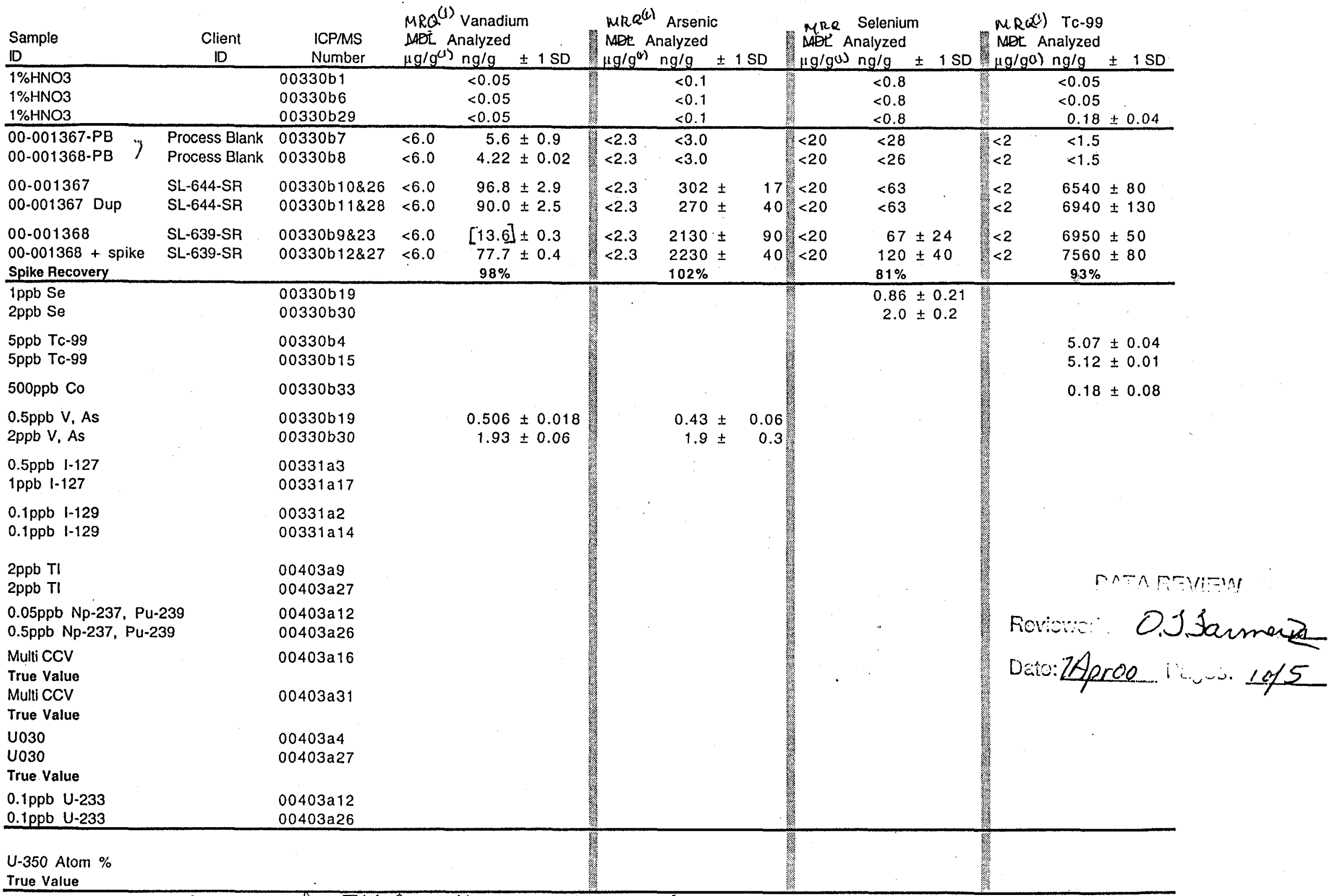

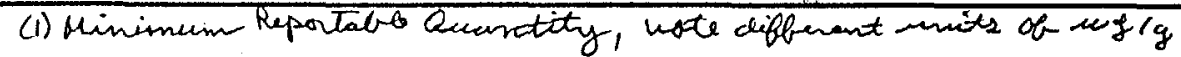




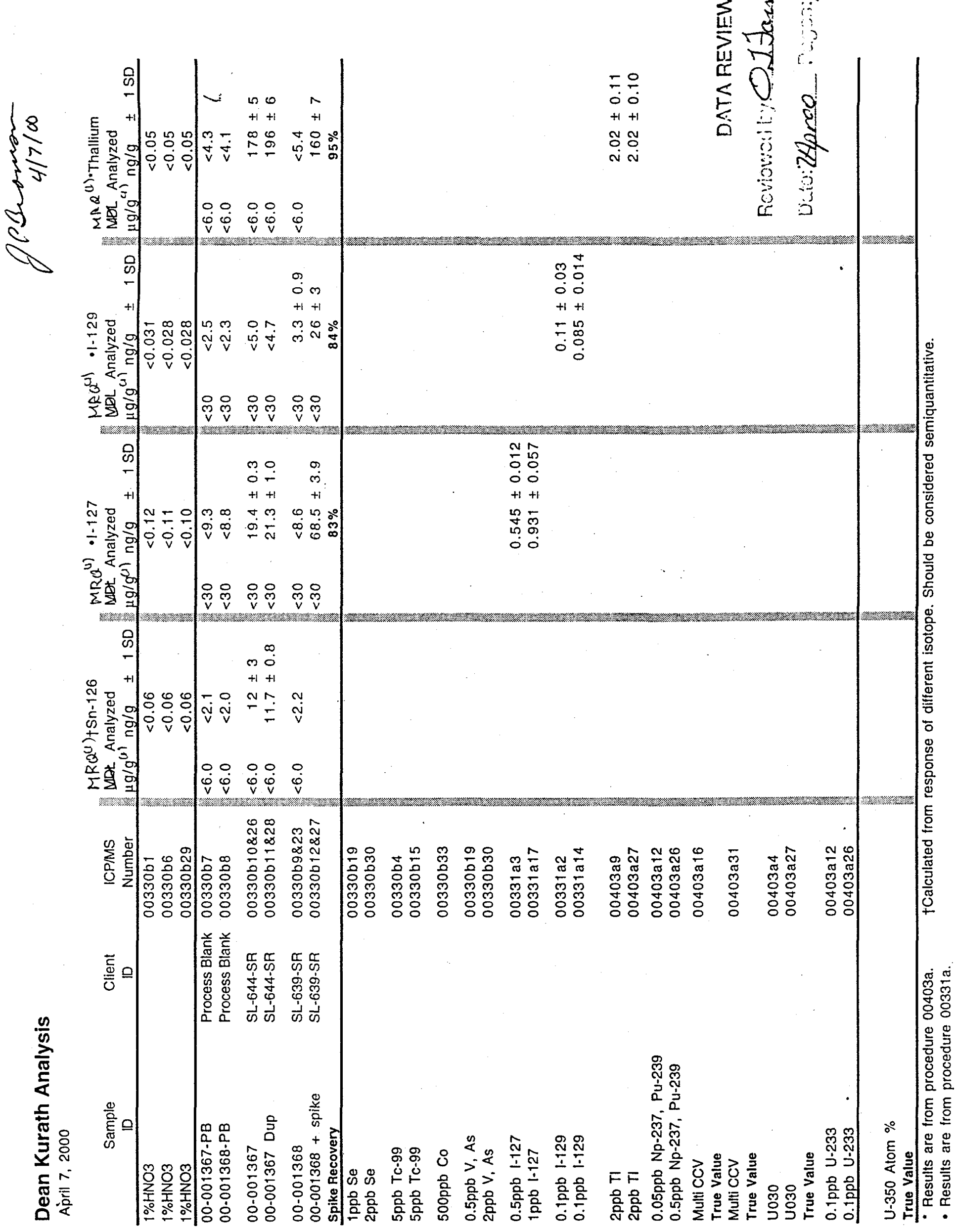


Dean Kurath Analysis

April 7, 2000

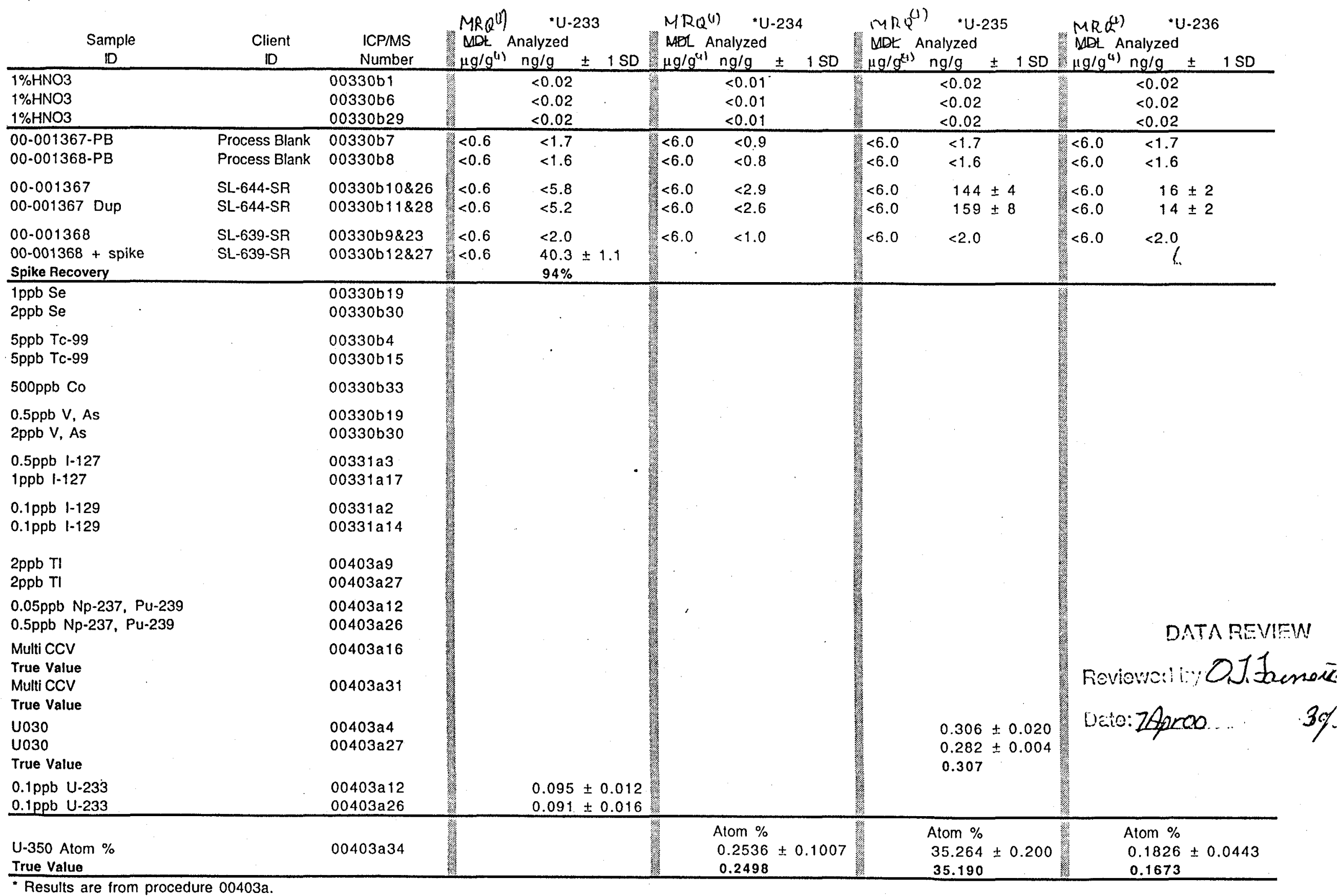


$\frac{3}{\frac{3}{2}}$

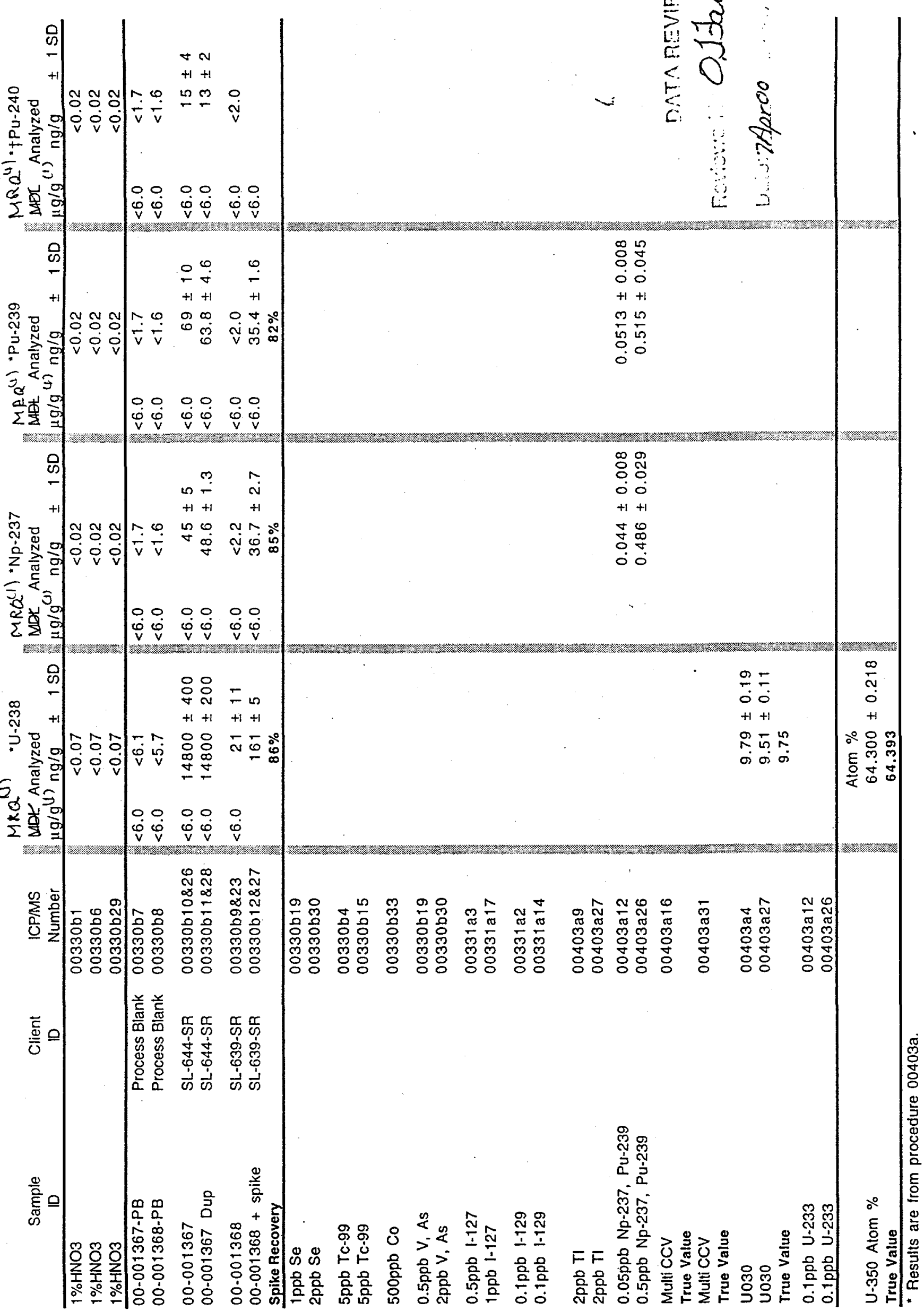




\section{Dean Kurath Analysis}

April 7, 2000

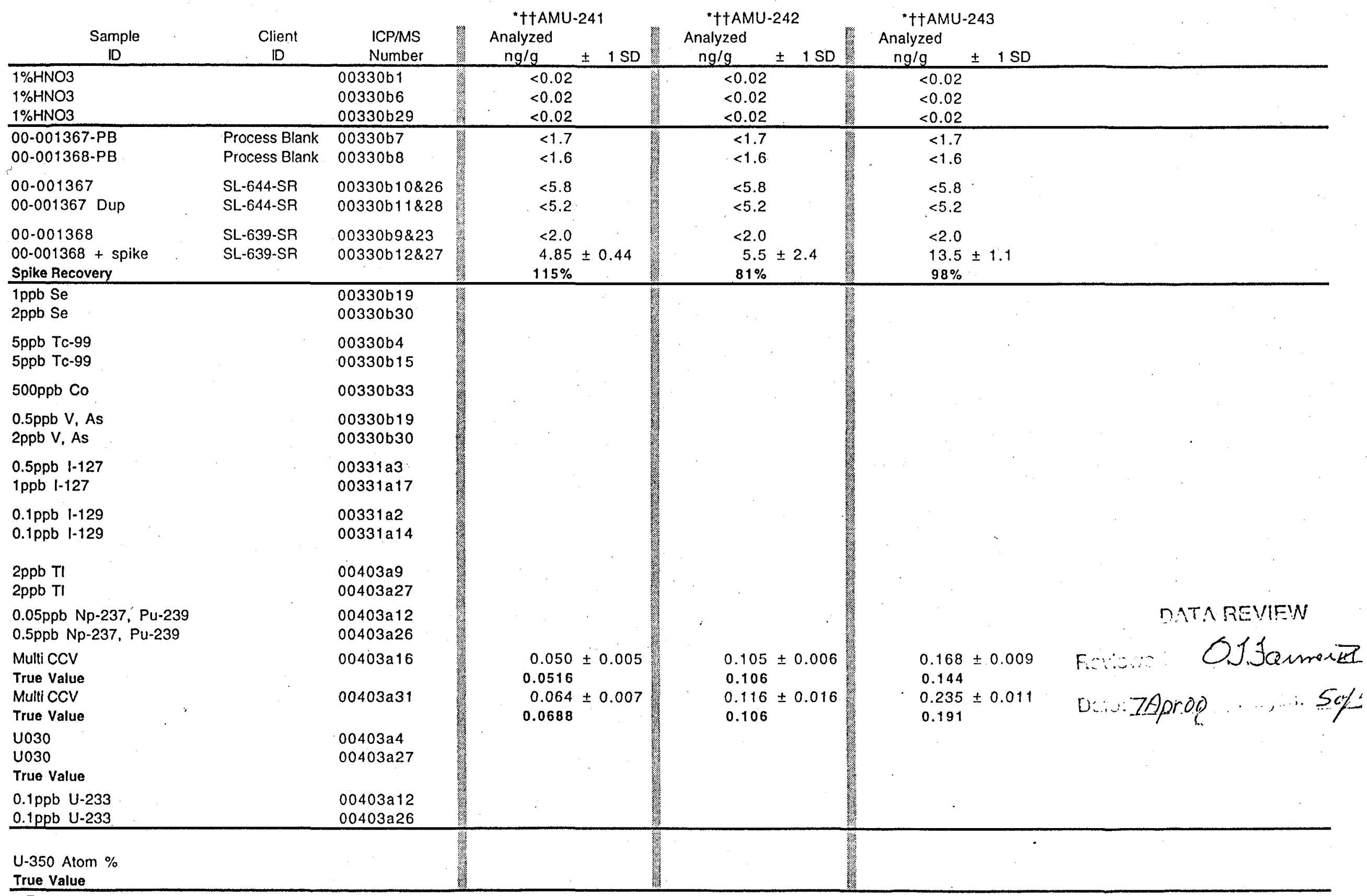

"Results are from procedure 00403a.

t†AMU-242 calculated using Pu-242. AMU-241,243 calculated using Am-241, Am-243 
ICP-MS Analysis of SL-644 and SL-639 Spent Resin

April 7,2000

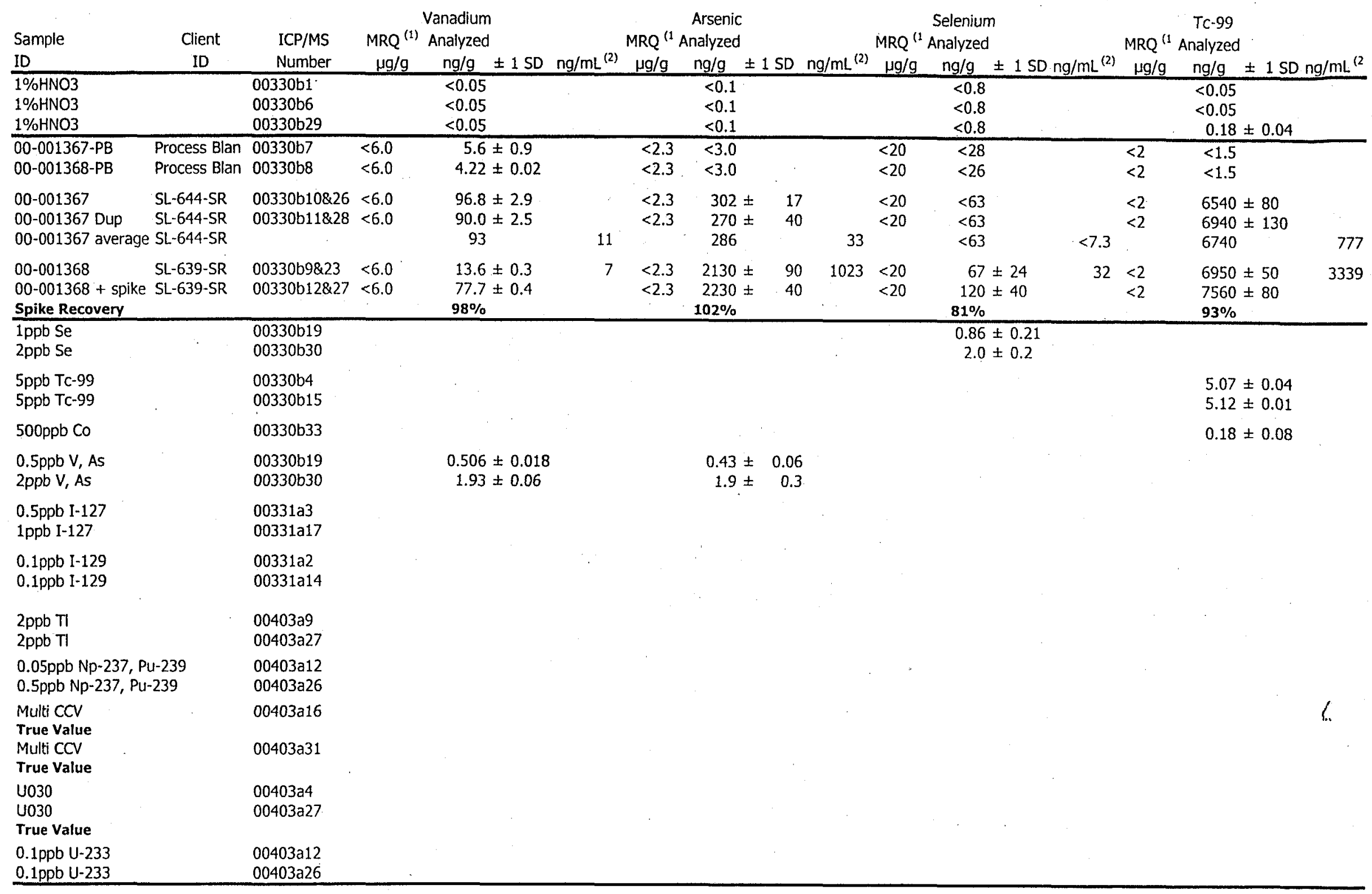

\section{U-350 Atom \%}

\section{True Value}

(1) MRQ = BNFL specified minimum reportable quantity. Note that the MRQ units are in $\mathrm{ug} / \mathrm{g}$ while analyte results are in $\mathrm{ng} / \mathrm{g}$.

(2) Concentration based on volume of resin subsample 
ICP-MS Analysis of SL-644 and SL-639 Spent Resin

April 7,2000

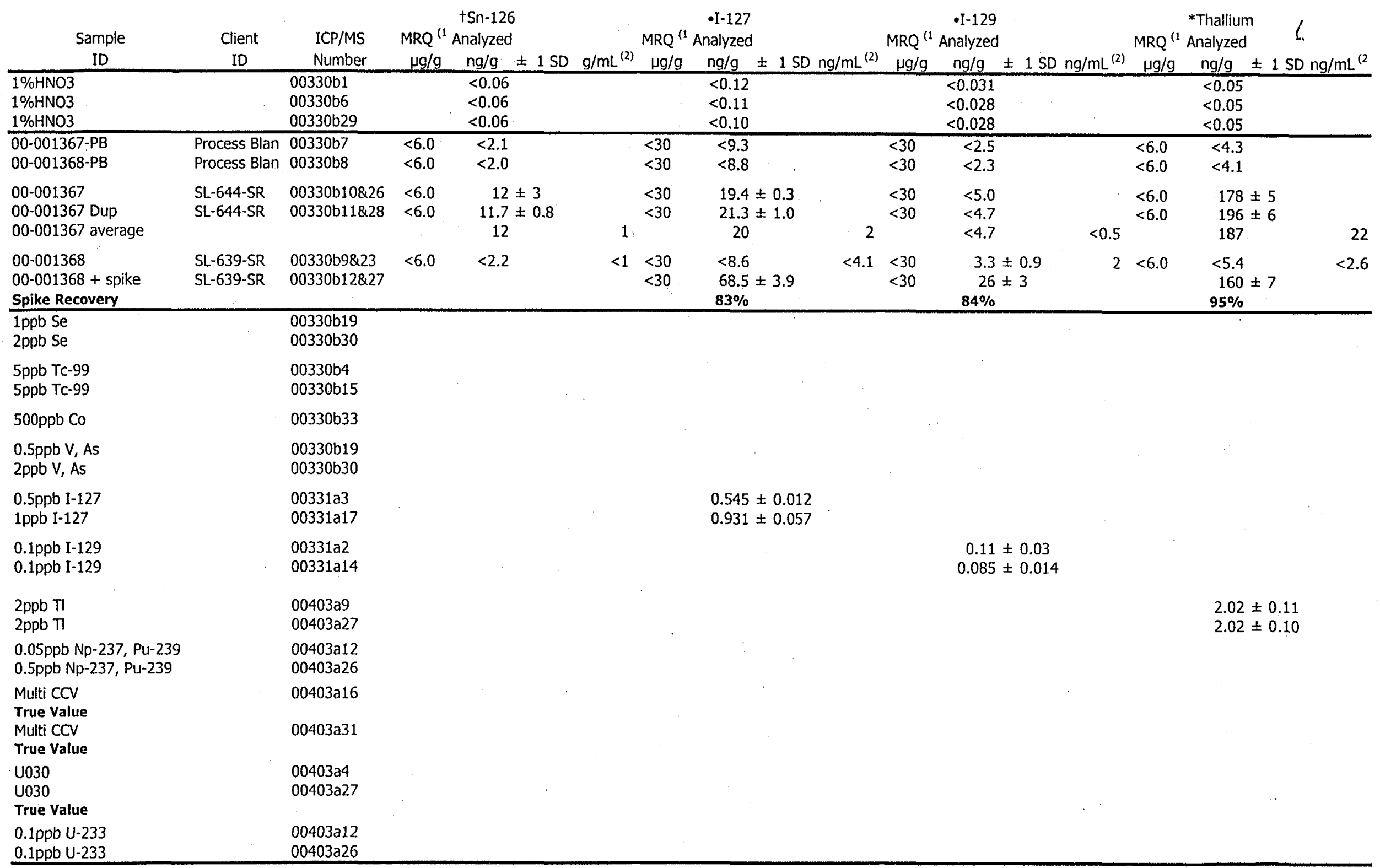

$\begin{array}{ll}\text { U-350 Atom \% } & \text { (1) MRQ = BNFL specified minimum reportable quantity. Note that the MRQ units are in ug/g while analyte results are in ng/g. }\end{array}$

True Value

(2) Concentration based on volume of resin subsample

* Results are from procedure 00403a. tCalculated from response of different isotope. Should be considered semiquantitative.

- Results are from procedure 00331 a. 
ICP-MS Analysis of SL-644 and SL-639 Spent Resin

April 7,2000

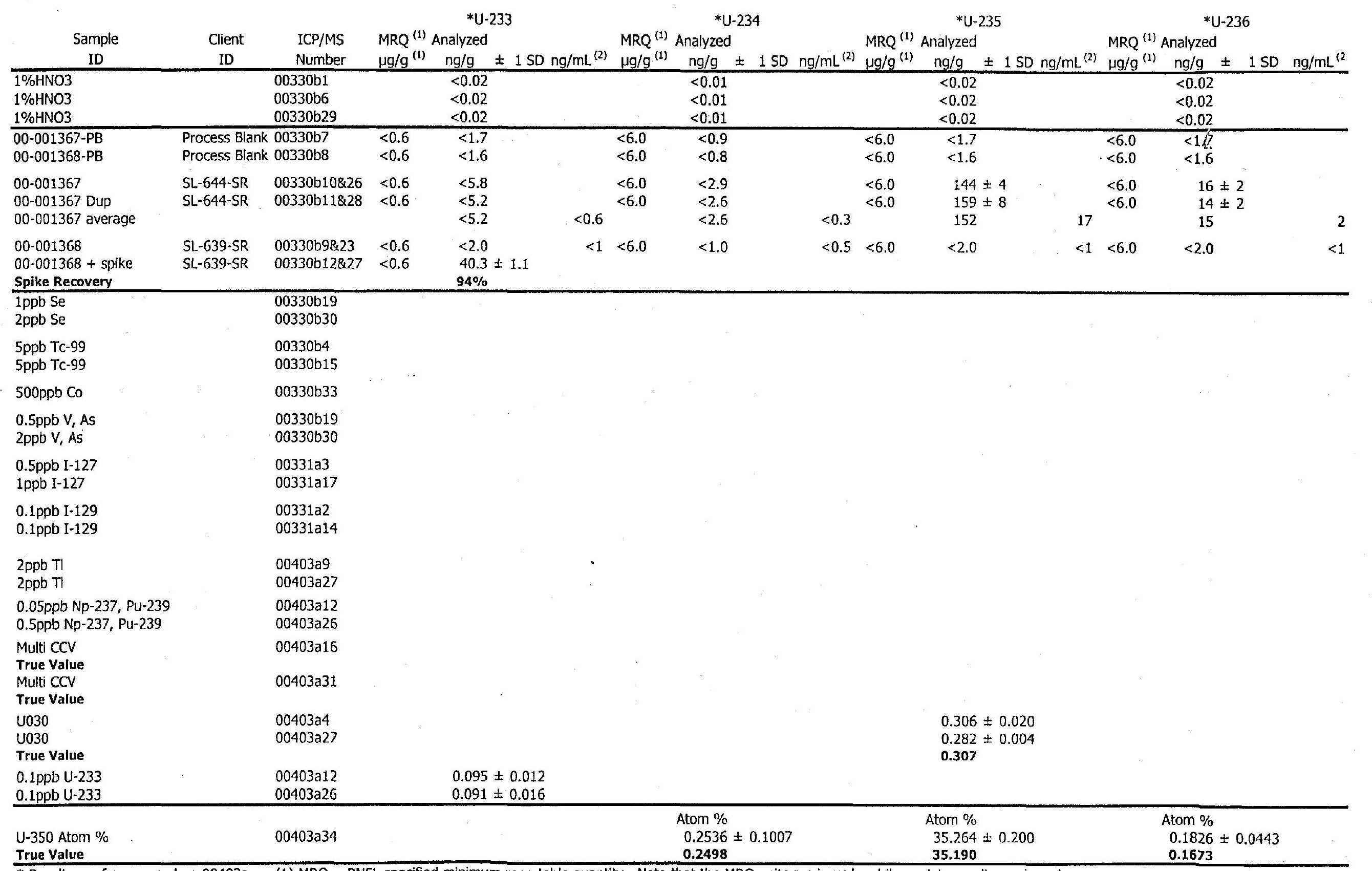

* Results are from procedure $00403 a$. (1) MRQ $=\mathrm{BNFL}$ specified minimum reportable quantity. Note that the MRQ units are in ug/g while analyte results are in ng/g. 


\section{ICP-MS Analysis of SL-644 and SL-639 Spent Resin}

April 7,2000

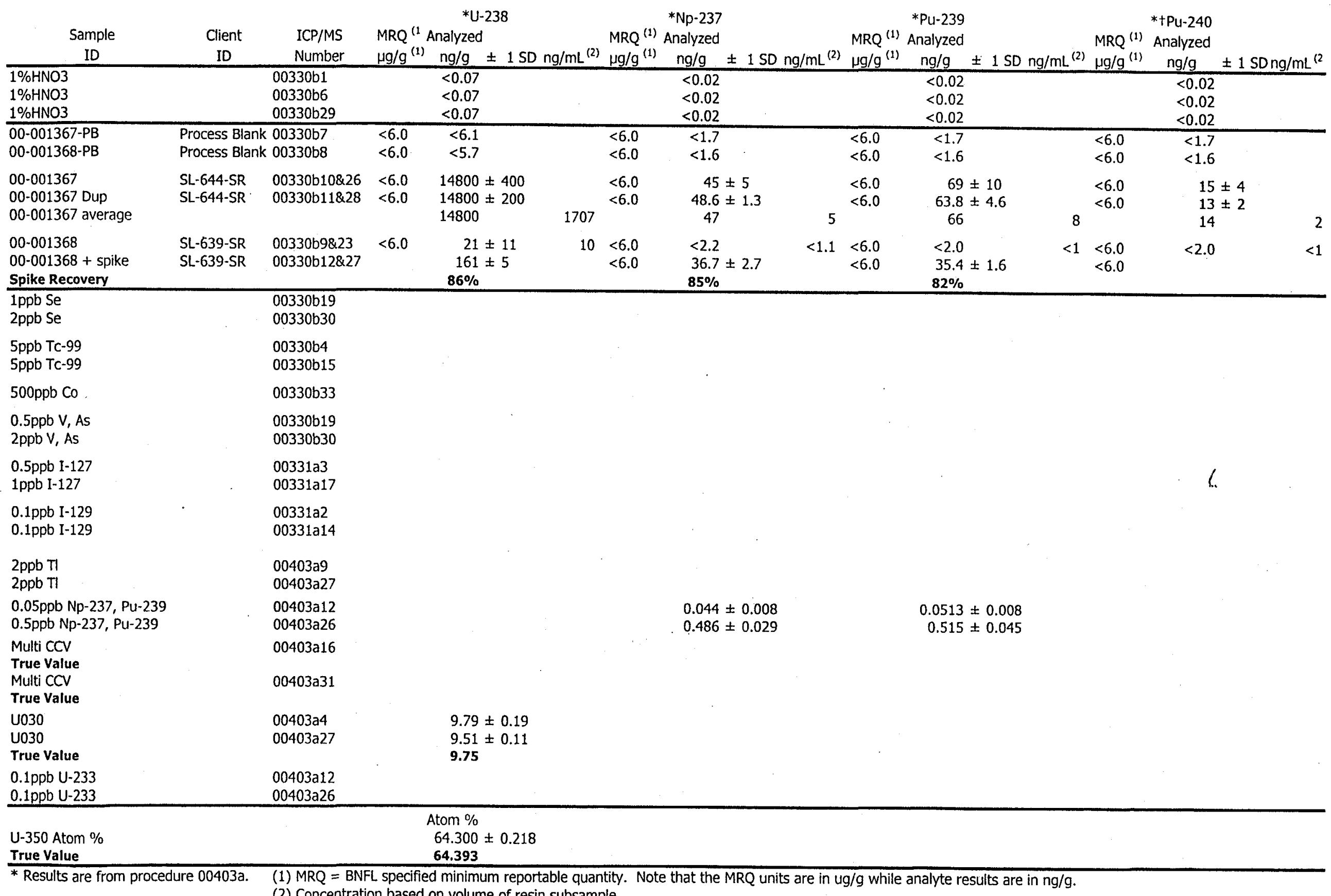

(2) Concentration based on volume of resin subsample 


\section{ICP-MS Analysis of SL-644 and SL-639 Spent Resin}

April 7,2000

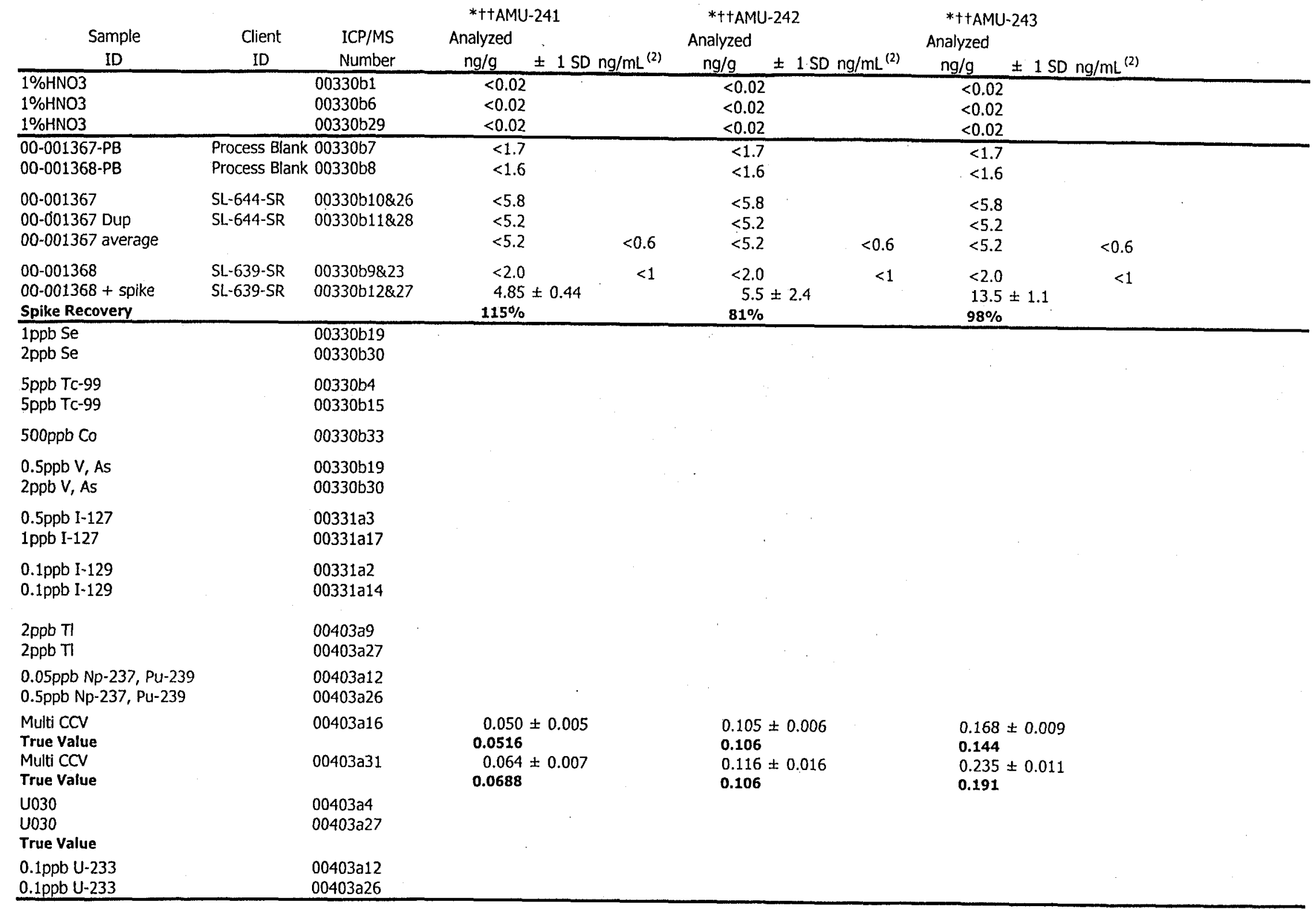

U-350 Atom \%

True Value

* Results are from procedure $00403 a$.

†+AMU-242 calculated using PU-242. AMU-241,243 calculated using Am-241, Am-243

(2) Concentration based on volume of resin subsample 


\begin{tabular}{|c|c|c|c|c|c|c|}
\hline \multicolumn{5}{|c|}{ preparation of resin samples for GEA, ICP-AES, ICP-MS } & \multirow[b]{2}{*}{$\begin{array}{c}\text { dry resin } \\
\text { @ } 95 \text { C } \\
\text { (2) }\end{array}$} & \\
\hline & vial tare & vial+resin & wet resin & $\begin{array}{c}\text { dry resin } \\
@ 95 \mathrm{C} \\
\text { (1) }\end{array}$ & & \\
\hline & $\mathrm{g}$ & $\mathrm{g}$ & g & g & g & \\
\hline SL-639-SR & 16.7666 & 19.6987 & 2.9321 & 1.2384 & 1.2251 & \\
\hline SL-644-SR & 16.9471 & 26.9733 & 10.0262 & 1.1659 & $1: 1532$ & \\
\hline \multicolumn{2}{|c|}{ SL-639 density @ 95 C = } & 0.48 & $\mathrm{~g} / \mathrm{mL}$ & & & \\
\hline \multicolumn{3}{|c|}{ estimated volume of SL-639 sample $=$} & 2.55 & $\mathrm{~mL}$ & & \\
\hline \multicolumn{7}{|c|}{$\begin{array}{l}\text { 1) This mass is determined by subtracting the tare weight of the vial from the mass } \\
\text { of the vial }+ \text { dry resin. } \\
\text { 2) This mass is determined by subtracting the water loss from the original sample } \\
\text { mass. The descrepancy appears to be due to the addition of a small radiation } \\
\text { sticker. This mass is therefore the mass used in calculations. }\end{array}$} \\
\hline & & & & & & \\
\hline \multirow[t]{2}{*}{ liquid samples } & vial tare & vial + liquid & liquid & & & \\
\hline & $g$ & $\mathrm{~g}$ & $\mathrm{~g}$ & & & \\
\hline SL-639-LQ & 16.6399 & 18.5687 & 1.9288 & & & \\
\hline \multirow[t]{2}{*}{ SL-644-LQ } & 16.7476 & 26.3832 & 9.6356 & & & \\
\hline & & & & & & \\
\hline \multicolumn{7}{|c|}{ preparation of resin samples for $\mathrm{Hg}$ analyses } \\
\hline \multirow[t]{2}{*}{ F factors } & vial tare & vial+resin & damp resin & water loss & $\begin{array}{l}\text { dry resin } \\
@ 95 \mathrm{C}\end{array}$ & F factor \\
\hline & g & g. & $g$ & $\mathrm{~g}$ & $g$ & \\
\hline SL-639-F & 18.8105 & 19.4884 & 0.6779 & 0.008 & 0.6699 & 0.988 \\
\hline \multirow[t]{3}{*}{ SL-644-F } & 18.7253 & 18.8954 & 0.1701 & 0.03 & 0.1401 & 0.824 \\
\hline & vial tare & vial+resin & wet resin & \multirow{4}{*}{\begin{tabular}{|c|} 
dry resin \\
$@ 95 \mathrm{C}$ \\
$\mathrm{g}$ \\
0.1051 \\
0.1071
\end{tabular}} & & \\
\hline & $g$ & $g$ & $g$ & & & \\
\hline SL-639-Hg-1 & 25.5936 & 25.7 & 0.1064 & & & \\
\hline $\mathrm{SL}-639-\mathrm{Hg}-2$ & 25.8151 & 25.9235 & 0.1084 & & & \\
\hline \multirow{3}{*}{$\begin{array}{l}\text { SL-644-Hg-1 } \\
\mathrm{SL}-644-\mathrm{Hg}-2 \\
\mathrm{SL}-644-\mathrm{Hg}-3\end{array}$} & 25.9315 & 26.033 & 0.1015 & \multirow{3}{*}{$\begin{array}{l}0.0836 \\
0.1030 \\
0.1036 \\
\end{array}$} & & \\
\hline & 25.6402 & 25.7652 & 0.125 & & & \\
\hline & 25.745 & 25.8708 & 0.1258 & & & \\
\hline & & & & & & \\
\hline & & & & & & \\
\hline
\end{tabular}




\begin{tabular}{|c|c|c|c|c|c|c|c|c|c|c|c|}
\hline & \multicolumn{5}{|c|}{ Radionuclide concentrations based on sample volume } & \multirow[b]{2}{*}{ Eu-154 } & \multirow[b]{2}{*}{ Eu-155 } & \multirow[b]{2}{*}{ Am-241 } & \multirow[b]{2}{*}{ Y-88 } & \multirow[b]{2}{*}{ Tc-95 } & \multirow[b]{2}{*}{ Tc-95M } \\
\hline & Co-60 & $5 \mathrm{~b}-125$ & Cs-134 & Cs-137 & CePr-144 & & & & & & \\
\hline & $\mathrm{uCi} / \mathrm{mL}$ & $\mathrm{uCi} / \mathrm{mL}$ & $\mathrm{uCi} / \mathrm{mL}$ & $\mathrm{uCi} / \mathrm{mL}$ & $\mathrm{uCi} / \mathrm{mL}$ & $\mathrm{uCi} / \mathrm{mL}$ & $\mathrm{uCi} / \mathrm{mL}$ & $\mathrm{uCi} / \mathrm{mL}$ & $\mathrm{uCi} / \mathrm{mL}$ & $\mathrm{uCi} / \mathrm{mL}$ & $\mathrm{uCi} / \mathrm{mL}$ \\
\hline \multicolumn{12}{|l|}{$00-1367$} \\
\hline SL-644-SR (1) & $1.51 \mathrm{E}-01$ & $<3 . E-3$ & $1.89 \mathrm{E}-03$ & $2.46 \mathrm{E}+00$ & $<4 . E-3$ & $7.60 \mathrm{E}-04$ & $1.65 \mathrm{E}-03$ & $1.03 E-03$ & & & \\
\hline & & & & & & & & & & & \\
\hline \multicolumn{12}{|l|}{$\overline{00-13} \overline{68}$} \\
\hline \multirow[t]{2}{*}{ SL-639-SR (2) } & $1.66 \mathrm{E}-04$ & $<1.6 \mathrm{E}-4$ & $<3.5 \mathrm{E}-5$ & $3.60 \mathrm{E}-05$ & $<4 \mathrm{E}-4$ & $9.25 \mathrm{E}-04$ & $8.78 \mathrm{E}-04$ & $5.13 \mathrm{E}-04$ & $5.84 \mathrm{E}-05$ & 1.27E-02 & $2.68 \mathrm{E}-01$ \\
\hline & & & & & & . & & & & & \\
\hline \multicolumn{12}{|l|}{$00-1369$} \\
\hline SL-644-LQ (1) & $8.22 \mathrm{E}-03$ & $4.98 \mathrm{E}-05$ & $2.31 \mathrm{E}-04$ & $1.61 \mathrm{E}-02$ & $6.05 \mathrm{E}-05$ & $1.36 \mathrm{E}-04$ & $9.34 \mathrm{E}-05$ & $2.35 \mathrm{E}-04$ & & & \\
\hline 644 LQ:SR & $5.44 \%$ & & $12.22 \%$ & $0.65 \%$ & & $17.89 \%$ & $5.66 \%$ & $22.82 \%$ & & & \\
\hline \multicolumn{12}{|l|}{$00-1370$} \\
\hline SL-639-LQ (3) & $<6 . \mathrm{E}-6$ & $<2$.E-5 & $<6 . E-6$ & $<7 . E-6$ & $<4 . E-5$ & $6.32 \mathrm{E}-05$ & $3.70 \mathrm{E}-05$ & $3.43 \mathrm{E}-05$ & & $2.11 \mathrm{E}-05$ & $3.45 \mathrm{E}-04$ \\
\hline $639 \mathrm{LQ}: \mathrm{SR}$ & & & & & & $8.54 \%$ & $5.27 \%$ & $8.35 \%$ & & $0.21 \%$ & $0.16 \%$ \\
\hline \multirow{3}{*}{\multicolumn{12}{|c|}{$\begin{array}{l}\text { 1) values based on an assumed } 10 \mathrm{~mL} \text { sample volume } \\
\text { 2) values based on a sample volume of } 2.55 \mathrm{~mL} \text {, estimated with the resin dry mass and density } \\
\text { at } 95^{\circ} \mathrm{C} \text {. } \\
\text { 3) values based on a } 2 \mathrm{~mL} \text { sample volume }\end{array}$}} \\
\hline & & & & & & & & & & & \\
\hline & & & & & & & & & & & \\
\hline & \multicolumn{5}{|c|}{ Radionuclide concentrations based on sample mass } & & & & & & \\
\hline & Co-60 & $\mathrm{Sb}-125$ & Cs-134 & Cs-137 & CePr-144 & Eu-154 & Eu-155 & $\mathrm{Am}-241$ & Y-88 & TC-95 & $\overline{\mathrm{TC}}-95 \mathrm{M}$ \\
\hline & $\mathrm{uCi} / \mathrm{g}$ & $\mathrm{uCi} / \mathrm{g}$ & uCi/g & $\mathrm{uCi} / \mathrm{g}$ & $\mathrm{uCi} / \mathrm{g}$ & $\mathrm{uCi} / \mathrm{g}$ & uCi/g & $\mathrm{uCi} / \mathrm{g}$ & $\mathrm{uCilg}$ & $\mathrm{uCi} / \mathrm{g}$ & $\mathrm{uCi} / \mathrm{g}$ \\
\hline \multirow{3}{*}{$\begin{array}{l}00-1367 \\
S L-644-S R(1)\end{array}$} & & & & & & & & & & & \\
\hline & $1.31 E+00$ & $<2.6 \mathrm{E}-2$ & $1.64 \mathrm{E}-02$ & $2.13 E+01$ & $<3.5 \mathrm{E}-2$ & $6.59 \mathrm{E}-03$ & $1.43 \mathrm{E}-02$ & $8.93 \mathrm{E}-03$ & & & \\
\hline & & & & & & & & & & & \\
\hline \multirow{3}{*}{$\begin{array}{l}00-1368 \\
S L-639-S R \text { (1) }\end{array}$} & & & & & & & & & & & \\
\hline & 3.45E-04 & $<3.3 \mathrm{E}-4$ & $<7.4 \mathrm{E}-5$ & $7.50 \mathrm{E}-05$ & $<8 \mathrm{E}-4$ & $1.93 \mathrm{E}-03$ & $1.83 \mathrm{E}-03$ & $1 . \overline{07} \mathrm{E}-03$ & 1.22E-04 & $2.64 \mathrm{E}-02$ & $5.58 \mathrm{E}-01$ \\
\hline & & & & & & & & & \multirow[b]{2}{*}{ 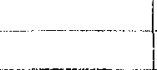 } & & \\
\hline \multirow{3}{*}{\begin{tabular}{|l|}
$00-1369$ \\
$S L-644-L$ \\
\end{tabular}} & & & & & & & & & & & \\
\hline & $8.53 \mathrm{E}-03$ & $5.17 \mathrm{E}-05$ & $2.40 \mathrm{E}-04$ & $1.67 \mathrm{E}-02$ & $6.28 \mathrm{E}-05$ & $1.41 E-04$ & $9.69 \mathrm{E}-05$ & $2.44 \mathrm{E}-04$ & $\cdots$ & & \\
\hline & & & & & & & & & & & \\
\hline \multirow{3}{*}{ SL-639-LQ (2) } & & & & & & & & & & & \\
\hline & $<6 . E-\overline{6}$ & $<2 . E_{-5}$ & $<6 . E-6$ & $<7 . E-6$ & $<4 . \bar{E}-5$ & $6.55 \mathrm{E}-05$ & $3.84 \mathrm{E}-05$ & $3.56 \mathrm{E}-05$ & 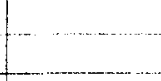 & $2.19 \mathrm{E}-05$ & $3.58 \mathrm{E}-04$ \\
\hline & & & & & & & & & & & \\
\hline & 2) Values b & ased on sam & nple mass ( & not dried). & Density sho & uld be clos & e to 1 as so & lution was & & & \\
\hline & & & & & & & & & & & \\
\hline & & & & & & & & & & & \\
\hline
\end{tabular}




\begin{tabular}{|c|c|c|c|c|c|c|c|c|c|}
\hline & Multiplier= & 17.2 & 17.2 & & & 16.1 & 16.1 & & \\
\hline & RPLLLAB \# & $=00-1367-\mathrm{PB}$ & $00-1367$ & & resin mass & $00-1368-\mathrm{PB}$ & $00-1368$ & & resin mass \\
\hline & Client $I D=$ & $\begin{array}{l}\frac{S L-644 S R}{\text { Process }} \\
\text { Blank (Wet: } \\
\text { Ashed) } \\
\end{array}$ & $\begin{array}{l}\text { SL-644-SR } \\
\text { Wet- } \\
\text { Ashed) } \\
\end{array}$ & & 1.1532 & \begin{tabular}{|l}
$\frac{\text { SL-639-SR }}{\text { Process }}$ \\
Blank (Dny- \\
Ashed) \\
\end{tabular} & $\frac{\text { SL-639-SR }}{\text { (Dry-Ashed) }}$ & & 1.2251 \\
\hline Det. Limit & Run Date= & $3 / 15 / 00$ & $3 / 15 / 00$ & detect limit & & $3 / 15 / 00$ & $3 / 15 / 00$ & detect limit & \\
\hline (ug/mL) & (Analyte) & $\mathrm{ug} / \mathrm{g}$ & $\mathrm{ug} / \mathrm{g}$ & $u g / g$ & $\mathrm{ug} / \mathrm{mL}$ & $\mathrm{ug} / \mathrm{g}$ & $\mathrm{ug} / \mathrm{g}$ & $\mathrm{ug} / \mathrm{g}$ & $\mathrm{ug} / \mathrm{mL}$ \\
\hline 0.015 & $\mathrm{Ag}$ & - & 5.03 & 0.26 & 0.58 & - & - & 0.24 & - \\
\hline 0.060 & $\mathrm{Al}$ & {$[2.8]$} & 60.9 & 1.03 & 7.0 & [0.99] & [6.5] & 0.97 & [3.1] \\
\hline 0.080 & As & - & - & 1.37 & - & - & [1.9] & 1.29 & {$[0.9]$} \\
\hline 0.050 & B & 39.4 & 170 & 0.86 & 20 & 26.4 & 89.9 & 0.81 & 43.2 \\
\hline 0.010 & $\mathrm{Ba}$ & - & {$[0.59]$} & 0.17 & {$[0.07]$} & - & [0.40] & 0.16 & [0.19] \\
\hline 0.005 & $\mathrm{Be}$ & -- & -- & 0.09 & -- & - & - & 0.08 & -- \\
\hline 0.100 & $\mathrm{Bi}$ & - & [9.8] & 1.72 & [1.1] & - & $\cdots$ & 1.61 & $\ldots$ \\
\hline 0.250 & $\mathrm{Ca}$ & [17] & 148 & 4.29 & 17 & - & [9.9] & 4.04 & [4.8] \\
\hline 0.015 & $\mathrm{Cd}$ & - & {$[0.56]$} & 0.26 & {$[0.06]$} & $\ldots$ & - & 0.24 & $\cdots$ \\
\hline 0.100 & $\mathrm{Ce}$ & - & $\ldots$ & 1.72 & -. & $\therefore$ & $\cdots$ & 1.61 & - \\
\hline 0.025 & Co & - & 70.9 & 0.43 & 8.2 & -- & - & 0.40 & $\ldots$ \\
\hline 0.020 & $\mathrm{Cr}$ & - & 669 & 0.34 & 77 & -- & 4.99 & 0.32 & 2.40 \\
\hline 0.015 & $\mathrm{Cu}$ & - & 116 & 0.26 & 13 & $\ldots$ & [1.1] & 0.24 & {$[0.5]$} \\
\hline 0.050 & Dy & - & -- & 0.86 & $=$ & - & -- & 0.81 & - \\
\hline 0.100 & Eu & - & - & .1 .72 & - & - & -- & 1.61 & - \\
\hline 0.025 & $\mathrm{Fe}$ & [2.3] & 84.2 & 0.43 & 9.7 & $\ldots$ & 30.4 & 0.40 & 14.6 \\
\hline 2.000 & $\mathrm{~K}$ & - & [222] & 34.31 & [26] & $\ldots$ & [162] & 32.30 & [78] \\
\hline 0.025 & $\mathbf{L a}$ & - & - & 0.43 & $\cdots$ & 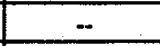 & - & 0.40 & - \\
\hline 0.020 & $\mathrm{Li}$ & - & - & 0.34 & 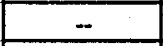 & - & - & 0.32 & $=$ \\
\hline 0.100 & $\mathbf{M g}$ & [2.8] & {$[5.8]$} & 1.72 & {$[0.7]$} & $\ldots$ & [6.2] & 1.61 & [3.0] \\
\hline 0.005 & Mn & - & 0.922 & 0.09 & 0.106 & - & 1.63 & 0.08 & 0.78 \\
\hline 0.030 & Mo & - & - & 0.51 & -- & - & $=$ & 0.48 & - \\
\hline 0.100 & $\mathrm{Na}$ & 70.5 & 83,813 & 1.72 & 9,665 & 40.8 & 2,295 & 1.61 & 1,102 \\
\hline 0.100 & Nd & - & - & 1.72 & $\ldots$ & 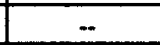 & 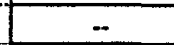 & 1.61 & -- \\
\hline 0.030 & $\mathrm{Ni}$ & [1.3] & 51.5 & 0.51 & 5.9 & [1.5] & {$[4.3]$} & 0.48 & [2.1] \\
\hline 0.100 & $P$ & -- & [9.1] & 1.72 & [1.0] & - & [6.5] & 1.61 & [3.1] \\
\hline 0.060 & $\mathrm{~Pb}$ & - & 10.9 & 1.03 & 1.3 & -- & -- & 0.97 & - \\
\hline 0.300 & $P d$ & - & - & 5.15 & - & - & {$[6.9]$} & 4.84 & [3.3] \\
\hline 0.300 & $\mathbf{R h}$ & -- & - & 5.15 & - & - & - & 4.84 & - \\
\hline 0.075 & $\mathbf{R u}$ & -- & [1.3] & 1.29 & [0.2] & -- & -- & 1.21 & - \\
\hline 0.050 & $\mathbf{S b}$ & $\ldots$ & - & 0.86 & - & - & - & 0.81 & $\ldots$ \\
\hline 0.050 & Se & -- & - & 0.86 & - & - & - & 0.81 & - \\
\hline 0.100 & $\mathrm{Si}$ & 19.7 & 22.8 & 1.72 & 2.6 & [2.6] & 39.7 & 1.61 & 19.1 \\
\hline 1.000 & Sn & -- & - & 17.15 & - & - & -- & 16.15 & -- \\
\hline 0.005 & $\mathrm{Sr}$ & $=$ & 1.57 & 0.09 & 0.18 & - & 2.43 & 0.08 & 1.17 \\
\hline 0.500 & $\mathrm{Te}$ & .. & - & 8.58 & - & - & - & 8.07 & $\ldots$ \\
\hline 0.800 & Th & $=$ & [14] & 13.72 & [2] & - & - & 12.92 & - \\
\hline 0.005 & $\mathrm{Ti}$ & - & 4.01 & 0.09 & 0.46 & - & {$[0.15]$} & 0.08 & {$[0.07]$} \\
\hline 0.250 & $\mathrm{TI}$ & - & - & 4.29 & - & - & - & 4.04 & - \\
\hline 2.000 & $U$ & - & - & 34.31 & - & - & - & 32.30 & - \\
\hline 0.015 & $v$ &.- & - & 0.26 & - & - & - & 0.24 & - \\
\hline 0.500 & $w$ & - & - & 8.58 & - & - & - & 8.07 & - \\
\hline 0.010 & $Y$ & - & - & 0.17 & - & - & - & 0.16 & - \\
\hline 0.020 & $\mathrm{Zn}$ & {$[0.89]$} & 20.6 & 0.34 & 2.4 & $\ldots$ & {$[0.45]$} & 0.32 & {$[0.22]$} \\
\hline \multirow[t]{5}{*}{0.025} & $\mathbf{Z r}$ & $-\approx$ & 181 & 0.43 & 21 & $=$ & -- & 0.40 & $=$ \\
\hline & & \multicolumn{6}{|c|}{ Note: 1$)$ Overall error greater than 10 -times detection limit is estimated to be within $+1-15 \%$. } & & \\
\hline & & \multicolumn{6}{|c|}{ 2) Values in brackets $\square$ are within 10-times detection limit with errors likely to exceed $15 \%$. } & & \\
\hline & & \multicolumn{6}{|c|}{ 3) "--" indicate measurement is below detection. Sample detection limit may be found by } & & \\
\hline & . & \multicolumn{5}{|c|}{ multiplying "det. limit" (far left column) by "multiplier" (top of each column). } & & & \\
\hline
\end{tabular}

